\title{
Galectins: Double-edged Swords in the Cross-roads of Pregnancy Complications and Female Reproductive Tract Inflammation and Neoplasia
}

\author{
Nandor Gabor Than ${ }^{1,2,3,4,5}$ \\ Roberto Romero ${ }^{1}$. Andrea Balogh ${ }^{1,6}$ \\ Eva Karpati, ${ }^{3,6}$ \\ Salvatore Andrea Mastrolia ${ }^{7,8}$ \\ Orna Staretz-Chacham ${ }^{9}$ \\ Sinuhe Hahn ${ }^{10}$. Offer Erez ${ }^{1,2,7}$ \\ Zoltan Papp ${ }^{4}$. Chong Jai Kim ${ }^{1,11,12}$ \\ ${ }^{1}$ Perinatology Research Branch, Eunice \\ Kennedy Shriver National Institute of Child Health \\ and Human Development, National Institutes \\ of Health, Department of Health and Human \\ Services, Detroit, MI, USA; ${ }^{2}$ Department of \\ Obstetrics and Gynecology, Wayne State \\ University School of Medicine, Detroit, MI, USA; \\ ${ }^{3}$ institute of Enzymology, Research Centre for \\ Natural Sciences, Hungarian Academy of \\ Sciences Budapest, Budapest, Hungary; \\ ${ }^{4}$ Maternity Private Department, Kutvolgyi \\ Clinical Block, Semmelweis University, Budapest, \\ Hangary; ${ }^{5}$ First Department of Pathology and \\ Experimental Cancer Research, Semmelweis \\ University, Budapest, Hungary; 'Department of \\ Immunology, Eotvos Lorand University, \\ Budapest, Hungary; ${ }^{7}$ Department of Obstetrics \\ and Gynecology, Ben-Gurion University, \\ Beer-Sheva, Israel; ${ }^{8}$ Department of Obstetrics \\ and Gynecology, University of Bari Aldo Moro, \\ Bari, Italy; 'Department of Neonatology, \\ Ben-Gurion University, Beer-Sheva, Israel; \\ ${ }^{10}$ Department of Biomedicine, University Hospital \\ Basel, Basel, Switzerland; "11Department of \\ Pathology, Wayne State University, Detroit, Ml, \\ USA; ${ }^{2}$ Department of Pathology, Asan Medical \\ Center, University of Ulsan College of Medicine, \\ Seoul, Korea
}

Received: February 18, 2015

Accepted: February 25, 2015

Corresponding Author

Nandor Gabor Than, M.D., Ph.D.

Institute of Enzymology, Research Centre for

Natural Sciences, Hungarian Academy of Sciences,

2 Magyar Tudosok korutja, Budapest H-1117,

Hungary

Tel: +36-1-382-6788

E-mail: than.gabor@ttk.mta.hu
Galectins are an evolutionarily ancient and widely expressed family of lectins that have unique glycan-binding characteristics. They are pleiotropic regulators of key biological processes, such as cell growth, proliferation, differentiation, apoptosis, signal transduction, and pre-mRNA splicing, as well as homo- and heterotypic cell-cell and cell-extracellular matrix interactions. Galectins are also pivotal in immune responses since they regulate host-pathogen interactions, innate and adaptive immune responses, acute and chronic inflammation, and immune tolerance. Some galectins are also central to the regulation of angiogenesis, cell migration and invasion. Expression and functional data provide convincing evidence that, due to these functions, galectins play key roles in shared and unique pathways of normal embryonic and placental development as well as oncodevelopmental processes in tumorigenesis. Therefore, galectins may sometimes act as double-edged swords since they have beneficial but also harmful effects for the organism. Recent advances facilitate the use of galectins as biomarkers in obstetrical syndromes and in various malignancies, and their therapeutic applications are also under investigation. This review provides a general overview of galectins and a focused review of this lectin subfamily in the context of inflammation, infection and tumors of the female reproductive tract as well as in normal pregnancies and those complicated by the great obstetrical syndromes. 


\section{INTRODUCTION TO THE GALECTIN FAMILY}

More than half of all human proteins are glycosylated, ${ }^{1}$ and glycans are attached to various additional glycoconjugates (e.g. glycolipids) besides glycoproteins. Because of the abundance of glycans intra- and extracellularly and also their high complexity, glycans can store orders of magnitude larger biological information than other biomolecules (e.g. nucleic acids and proteins)., ${ }^{2,3}$ Lectins are sugar-binding proteins, which are not an antibody or an enzyme, and can specifically bind glycans without catalyzing their modification. ${ }^{3,4}$ The interactions of lectins with glycans are pivotal in the regulation of a wide variety of interactions of cells with other cells, the extracellular matrix or pathogens. ${ }^{2-4}$

Galectins belong to a subfamily of lectins based on their unique structural and sugar-binding characteristics, since their carbohydrate-recognition domains (CRDs) contain consensus amino acid sequences and they specifically bind beta-galactoside-containing glycoconjugates. ${ }^{5-8}$ Galectins are the most widely expressed animal lectins; they have been found in species ranging from sponges to humans. ${ }^{7-9}$ They regulate a wide variety of key biological processes, such as cell growth, proliferation and differentiation, apoptosis, signal transduction, pre-mRNA splicing, as well as cell-cell and cell-extracellular matrix interactions. ${ }^{2,5-9}$ Galectins are also pivotal in immune responses since they regulate hostpathogen interactions, acute and chronic inflammation, and immune tolerance (Fig. 1) ${ }^{8,10-13}$ Moreover, some galectins are central to the regulation of angiogenesis in the placenta and in tumors. ${ }^{14,15}$ Interestingly, galectins can have opposing functions, and the same galectin can also have varying or contrasting effects based on the biological context and the microenvironment since their functions depend on the differentiation or activation status of the cell, the dynamic changes of their glycan partners on the cell surfaces, the redox and oligomerization status of the galectin, or its intra- or extracellular localization. ${ }^{8,11,16,17}$ Thus, galectins' double-edged action may sometimes be beneficial or harmful to the organism.

The fundamental functions of galectins indicate that they are strongly associated with reproductive functions as well as the establishment and maintenance of pregnancy. ${ }^{10,18-28}$ Indeed, some galectins are highly expressed at the maternal-fetal interface, ${ }^{10,18-39}$ and these are evolutionarily linked to placental evolution in eutherian mammals. ${ }^{5,7,9,26,27,40}$ Moreover, the dysregulated expression of these galectins in pregnancy complications has been increasingly documented..$^{10,23,32-36,38,41-51}$ Galectins have also been implicated in inflammatory, infectious and malignant diseases of the reproductive tracts. Of importance, the same galectins may be functional in pathways commonly shared by physiological and pathological, placental, and tumor developmental processes (e.g. cell invasion, angiogenesis, and immune tolerance). This review aims to give a general overview of galectins and also a focused review of them in the context of inflammation, infection and tumors in the female reproductive tract as well as in normal and complicated pregnancies.

\section{Structural features of mammalian galectins}

Galectins were originally termed "S-type lectins," where "S" refers to their free cysteine residues. ${ }^{6,8}$ Galectins or galectin-like proteins were also discovered in fungi, viruses, and even plants. ${ }^{8,9}$ Because of the diversity between mammalian and non-mammalian galectins, their nomenclature has diverged as mammalian galectins have been named using sequential numbering, while non-mammalian galectins have retained specific names (Table 1). ${ }^{6}$ Nineteen galectins have been identified in mammals to date, 13 of which were found in humans. ${ }^{9,27}$ These galectins can be divided into three structural groups: ${ }^{5-8}$ (1) "proto-type" galectins (-1, $-2,-5,-7,-10,-13,-14,-15,-16,-17,-19,-20)$ contain a single CRD of $\sim 130$ amino acids, which homodimerize, ${ }^{.5-5,52}$ (2) "tandem-repeat-type" galectins $(-4,-6,-8,-9,-12)$ contain two homologous CRDs connected by a short linker sequence. These may differ in their sugar-binding affinities and enable multivalent binding activity; ${ }^{5-7,52}$ and (3) "chimera-type" galectin-3, which contains a $\mathrm{C}$-terminal $\mathrm{CRD}$ and an $\mathrm{N}$-terminal non-lectin domain important for multimerization and cross-linking as well as functional regulation.-7,52

Although the amino acid sequences of galectins have diverged during evolution, the topologies of their CRDs are very similar, often described as "jelly-roll;" these are $\beta$-sandwiches consisting of five- and six-stranded anti-parallel $\beta$-sheets (Fig. 1).-8,53-55 Highly conserved in galectin CRDs are eight residues, which are involved in glycan-binding by hydrogen-bonds as well as electrostatic and van der Waals interactions. ${ }^{53,55}$ All galectins specifically bind beta-galactosides ${ }^{5-8}$ except galectin- 10 , which has more affinity to beta-mannosides. ${ }^{53}$ Of interest, some galectins have high affinity for poly-N-acetyllactosamine or $\mathrm{ABO}$ blood-group containing glycans, and the latter is responsible for their hemagglutinin activity. ${ }^{52,56-58}$

\section{Functional characteristics of mammalian galectins}

Galectins have multiple functions both inside and outside the cell (Table 1) ${ }^{8,59,60}$ Intracellularly, certain galectins can modulate cell growth, differentiation, apoptosis, and migration ${ }^{8,59,60}$ via protein-protein interactions. ${ }^{8,59,60}$ Some galectins (-1 and -3 ) 
shuttle into the nucleus where they function in pre-mRNA splicing. ${ }^{8.59}$ In spite of the fact that they do not have a secretory signal sequence, galectins can be secreted from cells via a non-classical pathway, avoiding the endoplasmic reticulum and Golgi apparatus, which is characteristic of only a small set of proteins (e.g. high-mobility group box 1 protein, interleukin-1 $\beta) .{ }^{61}$ Extracellularly, galectins predominantly localize to lipid rafts on cell surfaces $^{8,52,62}$ where they exert their functions through binding to cell-surface or extracellular matrix molecules, which carry their glycan ligands. ${ }^{2,7,8,11,13,52,63,64}$ They can form multivalent galectinglycan arrays, so-called lattices, by cross-linking their ligands on cell surfaces, and these lattices can organize lipid raft domains and modulate cell signaling for cell growth, metabolic functions, cytokine secretion, and survival, as well as many other intracellular and extracellular interactions. ${ }^{8,11,13,17,52,65}$ Some galectins can also affect cell adhesion and apoptosis, and activate or inhibit immune responses. ${ }^{8,11,13,63}$ An interesting trait of galectins is that their secretion is heightened upon response to stress conditions (e.g. inflammation and infection) and cellular damage (e.g. necrosis); therefore, galectins have been implicated as "alarmins" which signal tissue damage and elicit effector responses from immune cells, thereby promoting the activation and/or resolution of immune responses. ${ }^{12,35,64,66}$

\section{Expression profile of human galectins}

Accumulating evidence in various species shows that galectins have distinct but overlapping tissue expression patterns in mammals including humans (Table 1). 6,8,27,67,68 Among prototype galectins, galectin- 1 and galectin- 3 have a wide expression pattern in humans, galectin-1 being the most abundant in the endometrium/decidua. ${ }^{8,26,67}$ Among tandem-repeat-type galectins, galectin- 8 and galectin- 9 have a broad and complex expression pattern. Alternatively spliced isoforms of galectin- 8 are differentially expressed in various tissues ${ }^{8,39,67}$ similar to galectin- 9 , which is encoded by three genes. ${ }^{67}$ These galectins are highly expressed in the female reproductive tract and at the maternal-fetal interface. ${ }^{8,10,18-23,25,27,32,34,3,35,37-39,69}$ Some galectins $(-2,-4,-5,-6,-7$, -12) have more restricted tissue distribution. ${ }^{8,67}$ Of note, the expression of galectins in the chromosome 19 cluster is very restricted. Among these, galectin-10 is expressed in T regulatory (Treg) cells, as well as eosinophil and basophil lineages, and forms the so-called Charcot-Leyden crystals at sites of eosinophil-associated inflammation. ${ }^{53,70}$ The expression of galectin-13, -14 and -16 is predominant in the placenta, while galectin-17 expression is low in any tissues. ${ }^{27,29,67,71}$ Interestingly, these galectins (-10, $-13,-14,-16,-17)$, which are expressed from the chromosome
19 cluster, emerged via birth-and-death evolution in anthropoid primates and may regulate unique aspects of pregnancies, including maternal-fetal immune regulation and tolerance in these species. $^{16,27,72}$

\section{GALECTINS IN INFECTION AND INFLAMMATION OF THE FEMALE REPRODUCTIVE TRACT}

Due to the multiple functions of galectins, they have been implicated in pathways and processes fundamental for reproductive functions in both the pregnant and non-pregnant state. Data on the expression profile and functions of galectins regarding female reproductive tissues has recently emerged. Accordingly, a growing body of evidence suggests that galectins play important roles in immune responses in inflammatory and infectious diseases and in the development of various tumors of the female reproductive tract.

\section{Galectins in infection of the female reproductive tract}

Recent evidence suggests that the outcome of infection is also significantly influenced by galectins (Fig. 1) as these glycanbinding proteins acts as regulators of host-pathogen interactions. ${ }^{12}$ Similar to alarmins, upon tissue damage and/or prolonged infection, cytosolic galectins can be passively released from dying cells or actively secreted by inflammation-activated cells through the non-classical 'leaderless' secretory pathway. ${ }^{12}$ Once exported, galectins act as soluble or membrane-bound 'damage associated molecular patterns ${ }^{12,66}$ or "pathogen associated molecular patterns.' The latter, due to their CRDs, can specifically recognize pathogen cell surface antigens like pattern recognition receptors. ${ }^{12,66,73}$ Indeed, various galectins have been shown to bind a wide range of pathogens, which display their ligands on the surfaces, such as Gram-positive bacteria (e.g. Streptococcus pneumoniae), Gram-negative bacteria (e.g. Klebsiella pneumoniae, Neisseria meningitidis, Neisseria gonorrboeae, Haemophilus infuenzae, Pseudomonas aeruginosa, Porphyromonas gingivalis, and Escherichia coli), enveloped viruses (Nipah and Hendra paramyxoviruses, human immunodeficiency virus [HIV]-1, and influenza virus A), fungi (Candida albicans) and parasites (Toxoplasma gondii, Leishmania major, Schistosoma mansoni, Trypanosoma cruzi, and Trichomonas vaginalis). ${ }^{12,74-82}$

It is interesting that the co-evolution of microbes and host glycocalyx components is a continuously ongoing process, and the evolutionary arms race, the "Red Queen effect," has strongly impacted pathogenic and invasive properties of those microbes in 


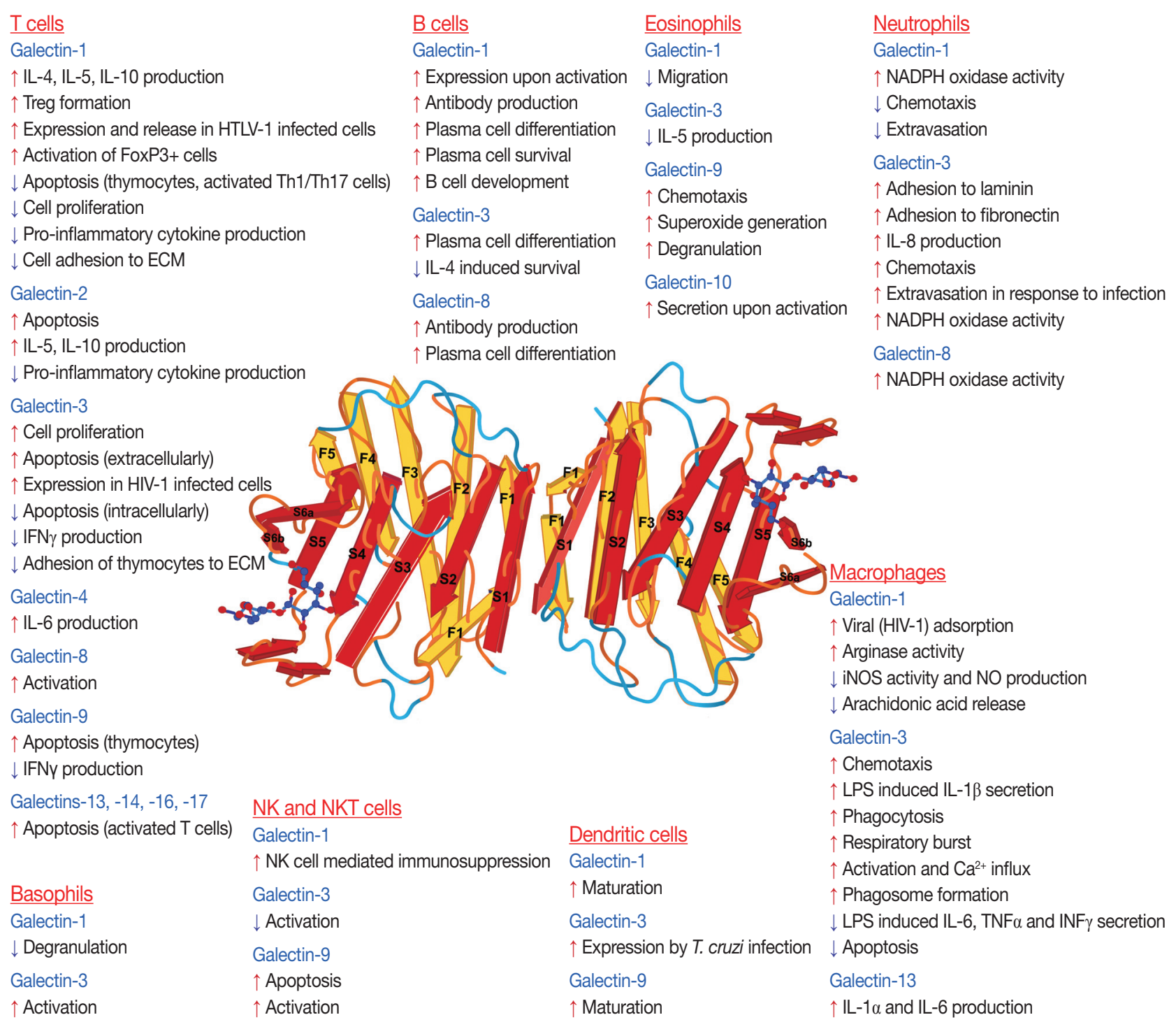

Fig. 1. Galectins in inflammation and infection. The effects and expression changes of galectins in immune cells are depicted around the three-dimensional model of galectin-1 (Protein Data Bank accession number: 1GZW) ${ }^{35,55}$ Galectins' effects are biological-context and microenvironment dependent and relate to the differentiation or activation status of the cell, the dynamic changes of the glycan partners of galectins on cell surfaces, the redox and oligomerization status of the galectin, or its intracellular or extracellular localization. ECM, extracellular matrix; HIV-1, human immunodeficiency virus 1; iNOS, inducible nitric oxide synthase; IFN, interferon; IL, interleukin; LPS, lipopolysaccharide; NK, natural killer; TNF, tumor necrosis factor. Parts of the figure are adapted from Than et al. Trends Endocrinol Metab 2012; 23: 23-31, with permission of Elsevier. ${ }^{16}$

relation to glycocalyx components that now infect our species. ${ }^{73,83}$ For example, it has been observed that galectin-3 provides advantage for Helicobacter pylori in binding to gastric epithelial cells, and thus, enhances the rate of infection. ${ }^{78}$ Similarly, galectin-1 increases the spread of human T-cell leukemia virus type I by stabilizing both virus-cell and uninfected-infected $\mathrm{T}$ cell interactions. ${ }^{79}$ Interestingly, due to their ligand-binding specificity, galectin-1, but not galectin-3, can influence the sexual transmission of HIV-1 through the increase of viral adsorption kinetics on monocyte-derived macrophages. ${ }^{77,84}$ Based on this data, the prog- ress of microbial infections seems to depend on the expression and localization of various galectins in the route of infection.

The most studied galectin in infections of the female reproductive tract is galectin-3. It is expressed on the apical side of the non-ciliated epithelial cells in the Fallopian tube and can bind the lipooligosaccharides on Neisseria gonorrboeae. Since galectin-3 participates in several endocytotic processes, such as its own reuptake, it can facilitate the invasion of human epithelial cells by gonococci. ${ }^{74}$ Interestingly, in response to gonococcal infection, tumor necrosis factor $\alpha$ production increases in the Fallopian 
Table 1. Mammalian galectins

\begin{tabular}{|c|c|c|c|}
\hline Galectin & Species & Human tissue and cell localization & $\begin{array}{l}\text { Participation in biological processes } \\
\text { relevant to tumors and pregnancy in mammals }\end{array}$ \\
\hline Galectin-1 & From fishes & $\begin{array}{l}\text { Adipose tissue, bone marrow, central nervous system, } \\
\text { endocrine glands, endothelia, female and male reproductive } \\
\text { systems, immune cells, lymphatic organs, placenta, } \\
\text { respiratory system, skin, smooth muscle }\end{array}$ & $\begin{array}{l}\text { Angiogenesis, apoptosis, cell adhesion, } \\
\text { proliferation, migration and invasion, inflammation } \\
\text { and infection, immune tolerance, immune } \\
\text { surveillance }\end{array}$ \\
\hline Galectin-2 & From fishes & $\begin{array}{l}\text { Blood, bone marrow, digestive tract, immune cells, } \\
\text { lymphatic organs, placenta, urinary tract }\end{array}$ & $\begin{array}{l}\text { Apoptosis, inflammation and infection, } \\
\text { tumor cell adhesion }\end{array}$ \\
\hline Galectin-3 & From fishes & $\begin{array}{l}\text { Adipose tissue, bone marrow, central nervous system, } \\
\text { digestive tract, endocrine glands, female and male } \\
\text { reproductive systems, heart muscle, immune cells, } \\
\text { lymphatic organs, placenta, respiratory system, skin, } \\
\text { smooth muscle, urinary tract }\end{array}$ & $\begin{array}{l}\text { Apoptosis, cell proliferation, migration and } \\
\text { invasion, inflammation and infection, } \\
\text { immune tolerance, immune surveillance, } \\
\text { tumor and immune cell adhesion }\end{array}$ \\
\hline Galectin-4 & From amphibians & Digestive tract, male reproductive system, skin & Inflammation, tumor cell adhesion \\
\hline Galectin-5 & Only in rodents & - & - \\
\hline Galectin-6 & Only in rodents & - & - \\
\hline Galectin-7 & From mammals & $\begin{array}{l}\text { Digestive tract, female reproductive system, } \\
\text { hearth, lymphatic organs }\end{array}$ & Apoptosis, cell proliferation \\
\hline Galectin-8 & From amphibians & $\begin{array}{l}\text { Bone marrow, digestive tract, endocrine glands, } \\
\text { female and male reproductive systems, immune cells, } \\
\text { lymphatic organs, placenta, urinary tract }\end{array}$ & Infection, tumor and immune cell adhesion \\
\hline Galectin-9 & From fishes & $\begin{array}{l}\text { Adipose tissue, bone marrow, digestive tract, } \\
\text { endocrine glands, female reproductive system, } \\
\text { immune cells, Iymphatic organs, placenta, } \\
\text { respiratory system, skin, smooth muscle }\end{array}$ & $\begin{array}{l}\text { Apoptosis, cell proliferation, migration, } \\
\text { inflammation and infection }\end{array}$ \\
\hline Galectin-10 & From primates & Bone marrow, immune cells, lymphatic organs & Inflammation, immune regulation \\
\hline Galectin-12 & From amphibians & $\begin{array}{l}\text { Adipose tissue, bone marrow, female reproductive system, } \\
\text { immune cells }\end{array}$ & Apoptosis, cell proliferation \\
\hline Galectin-13 & From primates & Placenta & Apoptosis, immune regulation, immune tolerance \\
\hline Galectin-14 & From primates & Placenta & Apoptosis, immune regulation, immune tolerance \\
\hline Galectin-15 & Ruminants & - & - \\
\hline Galectin-16 & From primates & Placenta & Apoptosis, immune regulation, immune tolerance \\
\hline Galectin-17 & From primates & Placenta & Apoptosis, immune regulation, immune tolerance \\
\hline Galectin-19 & New World Monkeys & - & - \\
\hline Galectin-20 & New World Monkeys & - & - \\
\hline
\end{tabular}

tube and induces apoptosis of cells not protected by galectin- 3 . Since the presence of gonococci is limited mainly to galectin-3positive non-ciliated cells, galectin- 3 promotes the survival of this pathogen. ${ }^{74}$ The induction of this anti-apoptotic effect of galectin- 3 can be observed when it is phosphorylated in response to infection, which increases the ability of galectin- 3 to induce arrest in the G1 growth phase ${ }^{85}$ and to perpetuate the survival and proliferation of infected cells. ${ }^{78}$

Besides galectin-3, galectin- 1 and -7 can also bind Trichomonas vaginalis. Surprisingly, the interaction of galectin-7 with this pathogen is not carbohydrate-mediated, in contrast to galectin-1, which is expressed by human cervical and vaginal epithelial cells, the placenta, as well as endometrial and decidual tissues. ${ }^{80,81}$ Galectin-1 and -3 are capable of binding purified lipophosphoglycan, which covers the whole surface of Trichomonas vaginalis. ${ }^{86}$ Galectin- 1 is thought to be a general attachment factor for this parasite and promotes the colonization of the female and male reproductive tracts, which could lead to vaginitis, bacterial vaginosis, increased risk of cervical cancer, human papillomavirus and HIV infection in females, endometritis, infertility, preterm birth, and low birth weight. ${ }^{81}$ In addition, female infants could get infected during birth and then would remain symptomless until puberty. ${ }^{87}$

In contrast to the harmful roles of galectins during Trichomonas vaginalis infection, upon invasion of this parasite, vaginal epithelial cells release galectin- 1 and -3 , and these galectins modulate vaginal epithelial cell inflammatory responses by triggering resident immune cells, and thus, contribute to the elimination of this pathogen. ${ }^{81}$ In addition, secreted galectin- 3 initiates the trafficking of phagocytic cells to the site of infection by supporting neutrophil adhesion to the endothelial cell layer, and this also increases its phagocytic activity. ${ }^{78,88}$

\section{Galectins in inflammation of the female reproductive tract}

Among various inflammatory diseases of the female reproductive tract, endometriosis has been the most studied in regard to 
galectins. Endometriosis is an inflammatory disease of reproductive-aged women, and it is strongly related to consequent infertility. ${ }^{89}$ The pathophysiology of endometriosis involves chronic dysregulation of inflammatory and vascular signaling, ${ }^{90}$ processes in which galectins are operational. Not surprisingly, galectin- 1 and -3 are overexpressed in various forms of endometriotic tissues. ${ }^{91-94}$ Moreover, higher galectin- 3 concentrations are also detected in peritoneal fluid samples from women with endometriosis than from controls. ${ }^{93}$ Functionally, it has been shown that corticotropin releasing hormone $(\mathrm{CRH})$ and urocortin, two neuropeptides that are also overexpessed in endometriosis, are involved in the up-regulation of galectin-1, acting through $\mathrm{CRH}$ receptor 1 , in a human endometrial adenocarcinoma cell line and in mouse macrophages. ${ }^{94}$ This up-regulation of galectin-1 may contribute to $\mathrm{T}$ cell apoptosis favoring the establishment, persistence and immune escape of endometriotic foci..$^{90}$ Moreover, galectin-1 may promote the vasculogenesis of endometriotic tissues since it orchestrates vascular networks in endometriotic lesions as demonstrated in mice with or without galectin-1 defi- ciency, ${ }^{92}$ and a neutralizing antibody against galectin-1 reduces the size and vascularized area of endometriotic lesions within the peritoneal compartment. ${ }^{92}$

Recent data have suggested that galectin- 3 may play a role in the development of pain due to endometriosis since it is involved in myelin phagocytosis, Wallerian degeneration of neurons, and triggers neuronal apoptosis induction after nerve injury. ${ }^{95}$ In fact, galectin-3, overexpressed in endometriotic foci, could induce nerve degeneration, since there is a close morphological relationship between nerves and endometriotic foci by means of perineurial and endoneurial invasion, especially in the most painful form of the disease. ${ }^{96}$ Interestingly, neurotrophin, a nerve growth factor strongly expressed in endometriosis, up-regulates galcetin-3 expression. ${ }^{91}$ These data underline the importance of galectin-1 and -3 in the pathogenesis of endometriosis.
Galectins' role in tumorigenesis

Angiogenesis

Galectin-3

$\uparrow$ Angiogenesis

Tumor invasion

Galectin-1

$\uparrow$ Tumor transformation

$\uparrow$ Cancer cell proliferation (intracellularly)

$\downarrow$ Cancer cell proliferation (extracellularly)

$\downarrow \uparrow$ Interactions during tumor invasion

Galectin-3

$\uparrow$ Cell-cell and cell-ECM interactions

$\downarrow$ Tumorigenicity in the nucleus

Galectin-7

$\uparrow$ Metastasis via regulating metastatic genes

$\uparrow$ Resistance to drug induced apoptosis

$\uparrow$ Cell migration

Galectin-8

$\uparrow$ Cell adhesion through certain integrins

Galectin-9

$\uparrow$ Tumor metastasis depending on isoform

Immune tolerance and tumor immune escape

Galectin-1

$\uparrow$ Apoptosis of activated T cells

$\uparrow$ Treg and DC activation

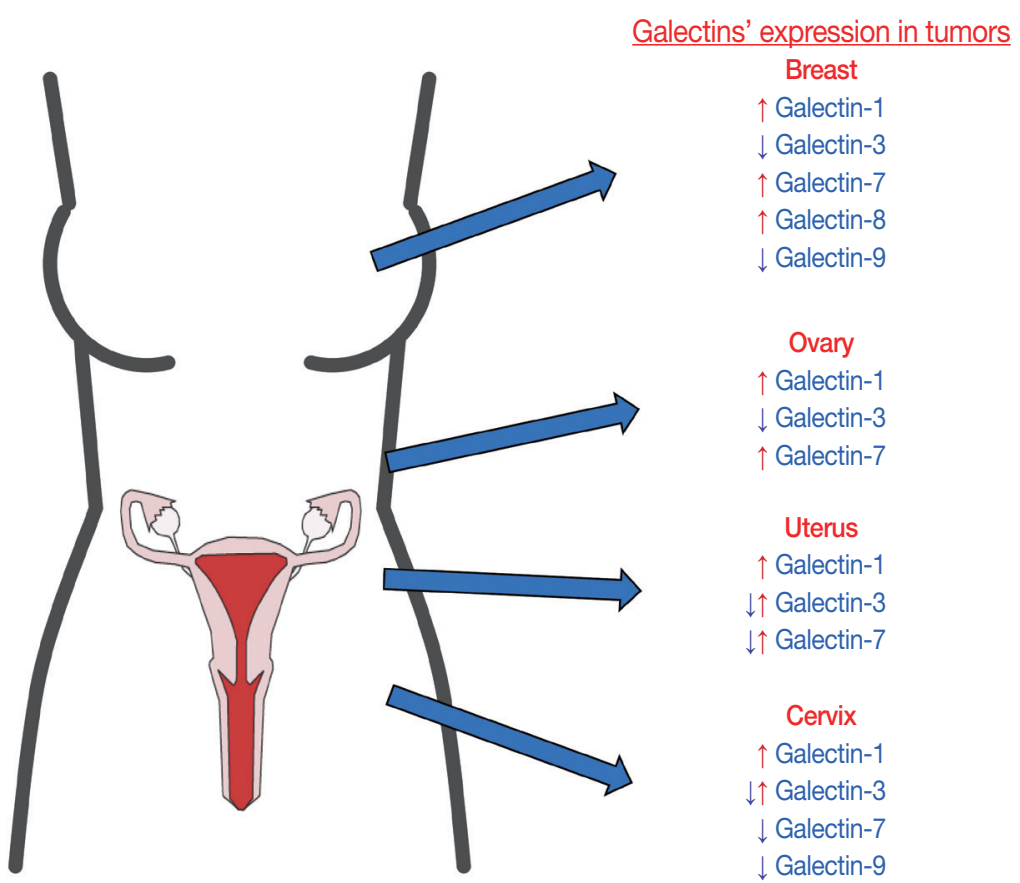

Galectin-9

$\uparrow$ Treg differentiation

$\uparrow$ Apoptosis of Th1 and Tc cells

$\downarrow$ Th17 differentiation

Fig. 2. Galectins in neoplasia of the female reproductive tract. The functional effects of various galectins in tumorigenesis and their expression changes in certain types of female tract neoplasia are depicted. The effects of galectins are biological-context and microenvironment dependent. Galectins' expression changes can be different according to the stage and type of various neoplasia as well as the type of the expressing cell. DC, dendritic cell. 


\section{GALECTINS IN TUMORS OF THE FEMALE REPRODUCTIVE TRACT}

The multifunctional role of galectins in cell growth, differentiation, apoptosis, adhesion, invasion, and angiogenesis explains why they are associated with different tumors. Indeed, many cancers have differential galectin expression compared to healthy controls, including tumors of the female reproductive tract (Fig. 2). ${ }^{97}$ Of interest, certain galectins have been functionally implicated in dysregulated pathways in tumor developmental processes, which are physiologically tightly regulated during placental development (e.g. invasion, angiogenesis, and immune tolerance). ${ }^{14,16,17,98}$ In addition, galectins may also be dysregulated in tumor-associated stromal cells or endothelial cells, ${ }^{15,99}$ and their glycan ligand expression and/or glycosylation pattern can also be affected. ${ }^{100,101}$ Most of these studies focused on galectin- 1 and -3 , but an increasing number of recent studies also investigated galectin-7, -8 , and -9 .

Galectin-1 is differentially expressed in several tumors in the female reproductive tract. An increased expression of galectin-1 protein is found in endometrial, ${ }^{102,103}$ breast, ${ }^{104}$ ovarian, ${ }^{105}$ and cervical $^{106}$ cancers. The intensity of galectin- 1 expression also increases according to the pathologic grade of cervical ${ }^{106}$ or breast $^{104}$ cancer and correlates with the depth of invasion of the cervical cancer and in lymph node metastases. ${ }^{107}$ In breast cancers, not only tumor cells but also cancer-associated stromal cells have elevated galectin-1 expression. ${ }^{99}$ In squamous cell carcinoma (SCC) of the uterine cervix, the intracellular expression of galectin-1 in tumor cells is higher than in the tumor-associated stroma, and galectin- 1 is an independent prognostic factor associated with local recurrence and cancer-specific survival in stage I-II cervical cancer patients undergoing definitive radiation therapy. ${ }^{108}$ It has been suggested that galectin-1 mediates radio-resistance through the H-Ras signaling pathway that is involved in DNA damage repair in cervical carcinoma cells, ${ }^{109}$ underlining the importance of galectin-1 in tumorigenesis and therapy.

Galectin-3 is down-regulated in cervical carcinomas, and its expression is correlated to histopathologic grades. ${ }^{110}$ It is also down-regulated in advanced uterine adenocarcinoma cells compared to normal adjacent endometrial cells. ${ }^{102,103}$ Moreover, galectin-3 expression is predominantly detected in the cytoplasm and/or nucleus of uterine or breast cancer cells. ${ }^{102,111,112}$ Of note, those uterine endometrioid adenocarcinomas, where galectin-3 is detected only in the cytoplasm, are characterized by deeper invasion of the myometrium. ${ }^{102}$ In addition, the neoplastic epithelium within 'MELF' (microcystic, elongated, and fragmented glands) areas shows a consistent reduction in galectin-3 protein expression, often contrasting with the adjacent galectin-3-positive conventional glands and reactive stromal cells. Conversely, intravascular tumor foci often show cytoplasmic and nuclear galectin-3 immunoreactivity. ${ }^{112}$ On the contrary, in some ovarian and endometrial carcinomas, including clear cell, serous, endometrioid, and mucinous ovarian carcinomas, higher galectin-3 expression is seen either by immunohistochemistry ${ }^{113-116}$ or by reverse transcription polymerase chain reaction. ${ }^{117}$ Which biological functions of galectin- 3 are utilized by tumor cells depends on the localization of this galectin: nuclear galectin- 3 may function in mRNA splicing, cell growth and cell cycle regulation; cytoplasmic galectin-3 may induce apoptosis resistance; and secreted galectin- 3 modulates cellular adhesion and signaling, immune response, angiogenesis and tumorigenesis by binding to cell surface glycoconjugates such as laminin, fibronectin, collagen I and mucin-1. ${ }^{111,118-121}$ For example galectin-3 may mediate chemoresistance via regulating the cell cycle as responders to chemotherapy have a higher proliferation activity than non-responders. This finding was strengthened by experimental results after knocking down galectin-3, which increases the fraction of cells in the S-phase of the cell cycle and decreases the expression of p27 cyclin dependent kinase inhibitor in clear cell carcinoma cell lines. ${ }^{114}$ Moreover, the ability of galectin- 3 to protect cells against apoptosis induced by various agents, working through different mechanisms, suggests that galectin-3 acts in a common central pathway of the apoptotic cascade, involving protection of mitochondrial integrity and caspase inhibition. ${ }^{85,122-128}$ Of importance, a galectin-3 polymorphism, the substitution of a proline with histidine $(\mathrm{P} 64 \mathrm{H})$, results in susceptibility to matrix metalloproteinase cleavage and acquisition of resistance to drug-induced (e.g. doxorubicin, staurosporine, and genistein) apoptosis, ${ }^{129-131}$ and homozygosity for this $\mathrm{H}$ allele is associated with increased breast cancer risk. ${ }^{130}$ On the other hand, the Pro64 variant and phosphorylation of galectin-3 at Ser6 seems to be important in tumor necrosis factor-related apoptosis-inducing ligand (TRAIL)-induced apoptosis of human breast carcinoma cells. ${ }^{131,132}$ Interestingly, nicotine induces the expression of galectin- 3 in breast cancer cells and in primary tumors from breast cancer patients through its receptor and STAT3 expression, increasing the anti-apoptotic effect of galectin- 3 , and suggesting detrimental effects of smoking. ${ }^{133}$

Galectin-7 up-regulation in cervical cancer is associated with better overall survival after definitive radiation treatment, ${ }^{134}$ and similar observations were made in other cancers (e.g. urothelial and colon), as well. ${ }^{135-138}$ On the other hand, galectin-7 induces 
chemoresistance in breast cancer cells via impairing $\mathrm{p} 53^{139}$ or via mutant p53-induced galectin-7 expression. ${ }^{140}$

Galectin-8 is expressed by various ovarian and breast cancer cell lines; ${ }^{141}$ however, only one study reported that breast cancer tissues constitute the only group of tissue to exhibit a higher immunohistochemical galectin-8 expression in the malignant, as opposed to the benign, tumors. ${ }^{142}$

Galectin-9 can be detected in normal epithelium and endocervical glands, and it has decreased expression in cervical intraepithelial neoplasia and SCC. High-grade intraepithelial lesions express less galectin-9 than low-grade lesions. Unexpectedly, galectin-9 expression is higher in well-differentiated SCC compared to moderate or poorly differentiated SCCs. These results imply the involvement of galectin-9 in the differentiation of cervical cancer cells. ${ }^{143,144}$ Recently, galectin-9 has been implicated as a prognostic factor in breast cancer. ${ }^{145}$ The various roles of galectin-9 in tumorigenesis, including the participation in apoptosis, cell cycle control, adhesion, aggregation, migration, invasion, metastasis, angiogenesis, and immune escape, have recently been summarized in a review. ${ }^{146}$

\section{Galectins in tumor invasion}

The invasive and metastatic phenotype of cancer cells is presumably associated with a specific pattern of expression of cell adhesion molecules that allows for crossing through the basement membranes and creating distant metastases. Emerging data demonstrate the role of galectins in metastasis events, although the data is conflicting, possibly due to the various effects that galectins may have according to the microenvironmental and physicochemical changes.

Galectin-1, a laminin-binding molecule, may contribute to the invasiveness of cancer cells, since higher galectin-1 binding to cancerous epithelial cells was observed in stage III/IV endometrial carcinomas than in lower stage tumors. ${ }^{102,147}$ Indeed, the down-regulation of galectin-1 by siRNA results in the inhibition of cell growth, proliferation and invading ability of various cervical cancer cell lines. ${ }^{107}$

Galectin-3, when localized to the cell surface, is involved in Thomsen-Friedenreich antigen (Gal $\beta 1-3 G a l N A c \alpha 1$ disaccharide)dependent homotypic cell adhesion and heterotypic cancer cellendothelial cell contact. ${ }^{148,149}$ Therefore, the decreased expression of this lectin could reflect the ability of cancer cells to detach from each other before invasion. Nuclear and cytoplasmic presence of galectin-3 implies that its localization and phosphorylation status is correlated with the proliferation status of the cells. ${ }^{150}$ All aspects of this topic have been reviewed elsewhere. ${ }^{151}$
Galectin-7 is also involved in the regulation of tumor growth and invasion. A recent in vitro study in human cervical SCC cell lines revealed that knocking down galectin-7 enhances tumor cell invasion and tumor cell viability against paclitaxel-induced apoptosis likely through increasing the matrix metallopeptidase (MMP)-9 expression and activating the phosphoinositide 3-kinase/Akt signaling pathway. ${ }^{152}$ However, more studies demonstrated that the expression of MMP-9 is increased by galectin-7 in cervical or ovarian cancer cell lines through the p38 mitogen activated protein kinase signaling pathway or mutant $\mathrm{p} 53$, respectively, resulting in increased cell invasion. ${ }^{153,154}$ In accord with this earlier study, high expression levels of galectin-7 are found exclusively in high-grade breast carcinomas; in a preclinical mouse model of breast cancer, high expression of galectin-7 significantly increases the ability of cancer cells to metastasize to lung and bone. ${ }^{155}$

\section{Galectins in tumor angiogenesis}

Galectin-3 is involved in tumor angiogenesis and invasion, as vascular endothelial growth factor $\mathrm{C}$ (VEGF-C)-mediated nuclear factor $\mathrm{kB}$ signaling pathway promotes invasion of cervical cancer cells via VEGF-C-enhanced interaction between VEGF receptor- 3 and galectin- $3 .{ }^{156}$ Moreover, the cleavage of galectin-3 and its subsequent release into the tumor microenvironment leads to breast cancer angiogenesis and progression as supported by the findings with BT-549-H(64) cells, in which galectin-3 increases chemotaxis, invasion and cancer cell-endothelial cell interactions resulting in angiogenesis and 3D morphogenesis. It is suggested that this in vitro angiogenic activity of galectin- 3 is related to its ability to induce the migration of endothelial cells. ${ }^{157}$ An in vivo study in immunocompromised mice transplanted with human breast cancer cells that overexpress galectin-3 showed increased density of capillaries surrounding the tumors, supporting that galectin-3 secreted by tumor cells induces angiogenesis. $^{158}$

In addition, endothelial cells also express several galectins (-1, $-3,-8$, and -9$)$ that may regulate tumor angiogenesis. For example, galectin-9 splice variants are expressed by endothelial cells, and their expression is regulated during endothelial cell activation. It is suggested that galectin-9 is possibly involved in attracting various immune cells (e.g. dendritic cells, DCs), which release angiogenic growth factors like VEGF, and its altered expression in the endothelium may interfere with a proper anti-tumor immune response. ${ }^{146}$ Additional data that has started to emerge on the role of galectins in tumor angiogenesis is reviewed elsewhere. $^{15}$ 


\section{Galectins in tumor immune tolerance}

Studies published to date mainly address the involvement of galectin-1 in tumor immune escape. Galectin-1 is involved in CD $4+C D 25+$ Foxp3 + Treg cell ${ }^{104}$ and tolerogenic DC activation, which may contribute to immune escape of tumor cells. ${ }^{159}$ Th1 cells are important in anti-tumor immune responses ${ }^{160}$ in all cancer types, and galectin-1 induces the selective apoptosis of Th1, Th17, and Tc lymphocytes in mice ${ }^{161}$ and humans. ${ }^{25}$ Of note, anti-galectin-1 antibody treatment in combination with cell therapy in a cervical cancer mouse model is more effective than the treatment with tumor infiltrating lymphocytes alone. ${ }^{162}$ This shows that inhibition of galectin-1 results in decreased immune escape of tumor cells. In addition, galectin-1 silencing in a breast cancer mouse model results in a marked reduction in tumor growth and lung metastases. ${ }^{104}$ These results suggest that galectin-1 blockade may be a good therapeutic approach, and further aspects on the roles of galectin- 1 in tumor formation and progression are reviewed elsewhere. ${ }^{163}$

Extracellular galectin-3 and galectin-7 induces apoptosis of T cells and peripheral blood mononuclear cells after binding to cell surface glycoconjugate receptors through carbohydrate-dependent interactions. ${ }^{154,164}$ In the case of galectin-3, CD7 and CD29 are identified as its apoptosis-inducing receptors. Furthermore, galectin-3-negative cell lines are significantly more sensitive to exogenous galectin- 3 than those expressing this lectin. This suggests crosstalk between the anti-apoptotic activity of intracellular galectin-3 and the pro-apoptotic activity of extracellular galectin-3, providing a new insight for the immune escape mechanisms of cancer cells.

Galectin-9 has immunosuppressive activity similar to galectin- $1 ;^{146}$ however, its role in tumor immune escape remains largely unexplored. Galectin-9 suppresses Th17 cell differentiation and induces the apoptosis of Th1 and Tc cells, while it enhances CD4 + CD25 + Treg cell differentiation, suggesting immunosuppressive functions of this lectin. On the other hand, galectin-9 was shown to induce the expansion of DCs and the subsequent potentiation of natural killer (NK) and Tc cell-mediated antitumor immunity in melanoma and sarcoma models, respectively, showing that galectin-9 may have various effects on immune escape. $^{146}$

\section{Galectins implicated as blood biomarkers of tumors}

A few studies have focused on determining the concentrations of certain galectins $(-1,-2,-3,-4,-8,-9)^{159,165,166}$ or galectin ligands ${ }^{167}$ in the sera of healthy people and cancer patients. The serum concentrations of galectin-2, $-3,-4$, and -8 were up to 31 - fold higher in patients with breast cancer than in controls, in particular those with metastasis. ${ }^{166}$ It is important, since the presence of galectin- 3 promotes cancer cell-endothelium adhesion in vitro via the interaction with the $\mathrm{T}$ antigen on cancer-associated mucin 1 . In addition, galectin-2, -4 , and -8 induce endothelial secretion of pro-inflammatory cytokines and chemokines in vitro, leading to the expression of endothelial cell surface adhesion molecules, and consequently increase cancer-endothelial adhesion and endothelial tube formation. ${ }^{159}$

Serum from breast cancer patients also contains an almost two-fold higher concentration of galectin-1 ligand glycoproteins. ${ }^{167}$ The most abundant ones are $\alpha$-2-macroglobulin, IgM and haptoglobin. In accordance, galectin-1-bound and nonbound haptoglobin uptake was also analyzed, and a dramatic difference was found in intracellular targeting, with the galectin-1 non-binding fraction targeted into lysosomes, while the galectin-1 binding fraction targeted into larger, galectin-1-positive granules. This suggests a major regulatory step in the scavenging of hemoglobin by haptoglobin, which can be altered in cancer. ${ }^{167}$

Galectin-3 concentrations in urine of various (e.g. breast, cervical, and ovarian) cancer patients and healthy controls showed a strong correlation between the stages of the disease and galectin-3 concentration. ${ }^{168}$

\section{GALECTINS IN PREGNANCY}

Pregnancy poses a substantial challenge to the maternal immune system. The semi-allogeneic fetus, placenta and chorioamniotic membranes continuously interact with maternal immune cells in the uterus, which is an immune privileged site, ${ }^{169}$ and those in the maternal circulation. ${ }^{170}$ During implantation and placentation, there is a continuous immune recognition and modulation of the maternal immune system by trophoblasts at the maternalfetal interface. ${ }^{171-174}$ Moreover, there is a continuous deportation of fetal cells and trophoblastic debris into the maternal circulation, which leads to microchimerism and an increase in systemic inflammation in the mother during pregnancy. ${ }^{175-179}$ Therefore, normal pregnancy is associated with a mild inflammatory state, especially by neutrophils of the innate immune system. ${ }^{180,181}$ This is significantly pronounced in preeclampsia, where the activation state of neutrophils is higher than in sepsis. ${ }^{182,183}$ Overtly activated neutrophils are also implicated in recurrent fetal loss or bacterially induced abortions. ${ }^{181}$ It was also revealed that other great obstetrical syndromes (e.g. intrauterine growth restriction [IUGR] and preterm labor) are also associated with various changes in the phenotypes as well as the behavior of maternal peripheral 
blood leukocytes and systemic inflammation. ${ }^{183-186}$ Since several galectins are expressed at the maternal-fetal interface, the site of contact between maternal and fetal cells that varies among different species, ${ }^{171,187-190}$ they are proposed to promote maternal-fetal immune tolerance and regulate local and systemic inflammation and infection. ${ }^{10,16,17,26,27}$ Indeed, changes in the expression of galectins $^{23,32-38}$ have been reported in the great obstetrical syndromes (e.g. preterm labor, preeclampsia), ${ }^{191}$ which are related to local and/or systemic inflammation and infection, and are responsible for most perinatal mortality and morbidity. ${ }^{192-205}$

\section{Galectin expression at the maternal-fetal interface in normal pregnancy}

The human maternal-fetal interfaces dynamically change during gestation. ${ }^{190}$ First, the syncytiotrophoblast is in direct contact with maternal cells in the decidua for a few days post-implantation and then with cells in the intervillous space. The latter is also the site of the interaction between the syncytiotrophoblast and maternal blood cells by the end of the first trimester, while invasive extravillous cytotrophoblasts in the placental bed and trophoblasts in the chorion laeve come into contact with maternal cells in the decidua. ${ }^{190}$ In this dynamic context, the expression of several galectins is also spatio-temporally regulated during development (Fig. 3). ${ }^{8}$ Galectin-1, -3 , and -9 are broadly expressed during human and mouse embryogenesis, suggesting that they may play a role in embryo development in mammals. ${ }^{8}$ Despite that, galectin-1 or galectin-3 knock out (KO) mice are viable, ${ }^{206}$ possibly due to the redundancy in galectin functions. ${ }^{8}$ In addition, galectin- $1,-3,-8,-9,-13,-14$, and -16 are also strongly expressed at the maternal-fetal interface in various mammals, some in a developmentally regulated fashion. . $6,18,19,21,23,27,32-34,39$

For example, galectin-1 expression is strong in the differentiated syncytiotrophoblast but not in the cytotrophoblast during first and third trimesters, ${ }^{19,207,208}$ and its expression in the extravillous trophoblast is developmentally regulated during the first-trimester. ${ }^{19,209}$ This latter phenomenon is also true for galectin- 3 , which also localizes to villous cytotrophoblasts. ${ }^{1,208}$ Galectin- 4 has weaker placental expression, ${ }^{27}$ which is down-regulated during trophoblast differentiation in rats. ${ }^{210}$ Galectin-8 has expression in villous and extravillous trophoblasts, ${ }^{39}$ while galectin-9 is mainly located in the decidua. ${ }^{16}$ RNA and protein evidence have shown that galectins in the chromosome 19 cluster (-13, -14, -16, and -17) are predominantly expressed by the syncytiotrophoblast but not by the underlying cytotrophoblasts. ${ }^{27,28,31,33,46,58}$ This is supported by galectin-13 immunolocalization to the multinucleated luminal trophoblasts within converted decidual spiral arterioles in the first trimester..$^{28} \mathrm{~A}$ recent study demonstrated that the expression of galectin-13, -14 , and -16 is related to the differentiation and syncytialization of the villous trophoblast, ${ }^{72}$ which is important in the production of placental hormones and immune proteins to control fetal development and immune tolerance. ${ }^{189,211,212}$ In vitro assays demonstrated that the expression of these galectins is related to syncytium formation induced by cAMP. ${ }^{72}$ Interestingly, the promoter evolution and the insertion of a primate-specific transposable element into the 5' untranslated region of an ancestral galectin gene introduced several binding sites for transcription factors fundamental in syncytiotrophoblastic gene expression, leading to the gain of placental expression of these chromosome 19 cluster galectins. ${ }^{72,213}$ Of note, DNA methylation also regulates the developmental expression of these genes ${ }^{72}$ similar to other galectins. ${ }^{214}$ Of interest, galectin- $1,-7,-9,-13$, $-14,-16$, and -17 are also expressed in the chorioamniotic membranes, but the developmental aspects of their regulation at this site have not yet been revealed. ${ }^{16,27,34,37,38}$

\section{Galectins in embryo implantation}

Embryonic implantation can be considered a pro-inflammatory response in the decidua, which involves the chemotaxis of leukocytes and their active participation in the regulation of implantation via secreted immune and angiogenic factors. ${ }^{25-218}$ Decidual cell-derived factors also have a key role in implantation. ${ }^{219}$ Of importance, several galectins are expressed by the uterine endometrium and decidua in mammals and are strictly regulated by sex steroids. ${ }^{18,22,220-222}$ The peak expression of these galectins coincides with the implantation time window; therefore, their possible roles in blastocyst attachment and in the regulation of immune cell functions during implantation have been implicated (Fig. 3). 18,21,22

For example, a temporal expression change of galectin-1, dependent on estrogen and progesterone, has been observed during the estrus cycle in mice. ${ }^{10,18}$ In humans, the expression of galectin- $1,-2,-3,-4,-8,-9$, and -12 is described in the endometri$u^{21,22,98,113,223-225}$ where galectin- 1 and galectin- 3 are highly expressed during the implantation time window. ${ }^{22,221}$ Galectin-3 expression is increased in glandular epithelial cells in the secretory phase, while galectin-1 expression is increased in stromal cells in the late secretory phase and further increased in the decidua. ${ }^{22}$ Interestingly, galectin-1 is also expressed in the trophectoderm and inner cell mass of human pre-implantation stage embryos, where it may be involved in the attachment to the uterine epithelium. ${ }^{226}$ In spite of the identification of galectin-3 in trophoblasts, its role in implantation has not been well de- 
Implantation

Galectin-1

$\uparrow$ Blastocyst attachment to uterine epithelium

Galectin-3

$\uparrow$ Blastocyst attachment to uterine epithelium

$\uparrow$ Blastocyst initial rolling

Galectin-9

$\uparrow$ Decidual cell migration

$\uparrow$ Decidual cell chemotaxis

Galectin-15

$\uparrow$ Blastocyst development

$\uparrow$ Blastocyst attachment to uterine epithelium

$\uparrow$ Implantation
Maternal-fetal immune tolerance

Galectin-1

$\uparrow$ Apoptosis of activated decidual $\mathrm{T}$ cells

$\downarrow$ T cell proliferation

$\uparrow$ Induction of tolerogenic DCs

$\uparrow$ Expansion of CD4+ CD25+ Treg cells

Galectin-8

$\uparrow$ Transformation of peripheral NK cells into uterine NK cells

Galectin-9

$\uparrow$ Establishment of an immuno-privileged environment for implantation

Galectin-13, -14, 16, -17

$\uparrow$ Apoptosis of activated T cells

\section{Angiogenesis / vascular effects}

Galectin-1

$\uparrow$ Production of angiogenic factors

$\uparrow$ Production of MMPs

$\uparrow$ Vascular development

$\uparrow$ Endothelial cell migration

$\uparrow$ Endothelial cell adhesion

Galectin-13

$\uparrow$ Vasodilatation

$\uparrow$ Utero-placental perfusion

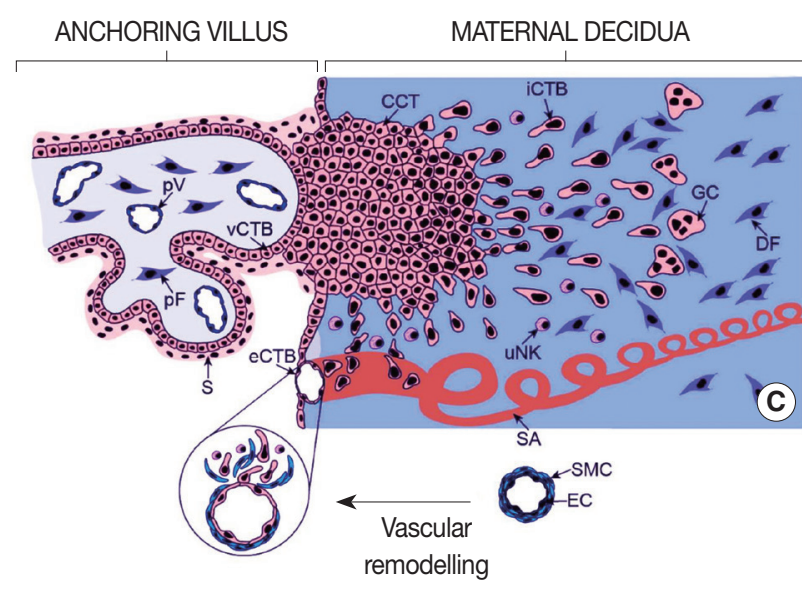

\author{
Trophoblast invasion \\ Galectin-1 \\ $\uparrow$ Trophoblast invasiveness \\ $\uparrow$ Organization of ECM \\ $\uparrow$ Cell adhesion in the cell columns \\ $\uparrow$ Production of MMPs \\ Galectin-3 \\ $\uparrow$ Organization of ECM \\ $\uparrow$ Cell adhesion in the cell columns \\ Galectin-8 \\ $\uparrow$ Organization of ECM \\ $\uparrow$ Cell adhesion in the cell columns \\ Galectin-13 \\ $\uparrow$ Trophoblast invasion
}

Fig. 3. Physiological aspects of galectins at the maternal-fetal interface. The figure represents multiple roles of galectins in implantation, angiogenesis, maternal-fetal immune tolerance and trophoblast invasion. (A) Embryo implantation. (B) Formation of primary villi by proliferative cytotrophoblasts. (C) Formation of tertiary villi, placental angiogenesis, extravillous trophoblast invasion and spiral artery remodeling. AE, amniotic epithelium; CCT, cell column trophoblast; DC, dendritic cell; DF, decidual fibroblast; EB, embryoblast; EC, endothelial cell; ECM, extracellular matrix; EM, extraembryonic mesoderm; eCTB, endovascular cytotrophoblast; GC, giant cell; ICM, inner cell mass, iCTB, interstitial cytotrophoblast; LUE, luminal uterine epithelium; L, lacunae; MMP, matrix metalloproteinase; NK, natural killer; pF, placental fibroblast; PS, primitive syncytium; pV, placental vessel; SA, spiral artery; S, syncytium; SMC, smooth muscle cell; TE, trophectoderm; UG, uterine gland; uNK, uterine NK cell; UV, uterine vessel; vCTB, villous cytotrophoblast. Cartoons are adapted from Knofler and Pollheimer. Front Genet 2013; 4: 190, under the terms of the Creative Commons Attribution License. ${ }^{217}$

fined.

Data in humans and mice support that galectin-9 is also involved in implantation. In mouse models, galectin-9 is associated with cell-to-cell interactions and the establishment of an immuno-privileged local environment for implantation and early fetal development as well as the mediation of decidual cell migration and chemotaxis. ${ }^{223}$ In humans, galectin- 9 is expressed by the endometrial glandular epithelial cells during the implantation time window as well as by the human decidua during early pregnancy. ${ }^{21}$ Electron microscopy clarified its localization on the apical projections of the human endometrial epithelium called uterodomes, ${ }^{223}$ which are membrane projections that exclusively feature the receptive endometrium during the implantation time window. The contribution of galectin-9 to the development of pregnancy is supported by the observation that normal pregnancy and cases of spontaneous abortions differ significantly in terms of endometrial galectin- 9 splice variant profiles in both mice and humans. ${ }^{227}$

\section{Galectins in trophoblast invasion}

A growing body of evidence suggests that human galectins play key roles in placentation events beyond implantation. For example, galectin- $1,-3$, and -8 are expressed in the extravillous trophoblast in the first trimester ${ }^{19,39}$ throughout the invasive 
pathway of trophoblast differentiation. ${ }^{212,217,228}$ These galectins are expressed in extravillous trophoblast cell columns, where they actively deposit extracellular matrix and can bind to major structural glycans of the placental bed (e.g. fibronectin and laminin), ${ }^{8,19,39,229}$ Thus, galectin- $1,-3$, and -8 may play a role in the organization of the extracellular matrix and the modulation of cell adhesion in the cell columns. ${ }^{19,39}$ In addition, galectin- 1 and -3 may have a role in the regulation of the extravillous trophoblast cell cycle since they are absent from the differentiated, nonproliferating, interstitially migrating, highly invasive cytotrophoblasts (Fig. 3). ${ }^{19}$

Not only the expression pattern of galectin- 1 in the first trimester placenta but also the findings that blocking galectin-1 substantially abrogates migration of primary trophoblasts and HTR8/SVneo cells cultured in matrigel ${ }^{19,209}$ suggest that galectin-1 modulates the invasive pathway of trophoblast differentiation and enhances trophoblast invasiveness. Extravillous trophoblastic galectin- $3^{19,208}$ may interact between cell and extracellular matrix components, modulating adhesive interactions and immune reactions as observed in a murine model. ${ }^{230}$

In the case of galectin-13 (PP13), a different mechanism is proposed to promote trophoblast invasion. ${ }^{28}$ Galectin-13 is secreted by the syncytiotrophoblast to the maternal circulation, from where it is transferred into the decidua in the first trimester, coinciding with the time of early trophoblast invasion. Interestingly, galectin-13 forms crystal-like aggregates in the decidua, where it attracts, activates and kills maternal immune cells, diverting them from spiral arterioles and invading trophoblasts. ${ }^{28}$ In this manner, PP13 may serve to establish a decoy inflammatory response, sequestering maternal immune cells away from the site of extravillous trophoblast spiral artery modification.

\section{Galectins in maternal-fetal immune tolerance}

In eutherian mammals multiple immune mechanisms exist which support the establishment and maintenance of immunological privilege in the pregnant uterus, as well as antigen-specific, local and systemic maternal-fetal tolerance. ${ }^{10,26,27,171-174,192}$ These mechanisms are strongly affected by the type of placentation and the interactions between fetal trophoblasts and maternal immune cells at the maternal-fetal interfaces. ${ }^{171,187,189}$ In this regard, it is important to note that galectins are also expressed by maternal immune cells, which infiltrate the decidua and play key roles in mammalian pregnancies (Fig. 3). ${ }^{20,25,51,70,231}$

For example, galectin- 1 is strongly expressed by uterine natural killer (uNK) cells compared to peripheral blood NK cells. ${ }^{20}$ These CD $56+$ galectin- $1+$ uNK cells comprise $~ 70 \%$ of maternal leukocytes at the implantation site, promote angiogenesis and trophoblast invasion ${ }^{20,171}$ and are pivotal for the maternal adaptation to pregnancy. ${ }^{232}$ Galectin-1, secreted by human uNK cells, induces apoptosis of activated decidual $\mathrm{T}$ cells, ${ }^{25}$ which is supported by data indicating that galectin-1 can selectively induce apoptosis of Th1 and Th17 cells ${ }^{25,63}$ and contribute to maternal immune-tolerance to the semi-allogeneic fetus. ${ }^{10,25,26}$ In addition, galectin-1 is among the immunosuppressive molecules secreted by villous trophoblasts, which were identified by a proteomics study and found to inhibit $\mathrm{T}$ lymphocyte proliferation and adaptive immune responses. ${ }^{69}$ The villous trophoblast secretes other galectins, expressed from the chromosome 19 galectin cluster $(-13,-14$, and -16), which induce the apoptosis of activated $\mathrm{T}$ cells, and thus, are assumed to exert special homeostatic and immunobiological functions at the maternalfetal interface. ${ }^{16,27}$

As in vivo evidence for the pivotal functions of human galectin-1, a proteomics study identified it to be down-regulated in villous placenta in early pregnancy loss, reflecting abnormalities in the support for the maintenance of pregnancy. ${ }^{23}$ Other in vivo evidence comes from a mouse model of stress-induced fetal loss in which the decidual expression of galectin-1 decreased, and these mice, similar to galectin-1 KO mice, had a higher rate of fetal loss in allogeneic pregnancies. ${ }^{10}$ This effect was reversed by the administration of recombinant galectin- 1 and also by progesterone treatment, supporting the progesterone-dependent regulation of decidual galectin-1 expression. Galectin-1 treatment also prevents the drop in progesterone and progesteroneinduced blocking factor serum concentrations in stressed animals, suggesting a synergistic effect of galectin- 1 and progesterone in pregnancy maintenance. ${ }^{10}$ It was also elucidated that galectin-1 exerts its immune modulatory effect through the induction of tolerogenic DCs, which in turn trigger the expansion of interleukin-10 expressing CD4+CD25+Treg cells in vivo. ${ }^{10}$ Subsequently, it was determined that Treg cells, which normally expand during pregnancy and suppress the maternal allogeneic response directed against the fetus, ${ }^{187}$ also overexpress galectin-10, which has an important role in suppressive functions. ${ }^{70,231}$

The galectin-9/TIM-3 (T-cell immunoglobulin domain and the mucin domain 3) pathway has been recognized as central in the regulation of Th1 immunity and tolerance induction. ${ }^{233,234}$ Very recently, galectin-9 was also implicated in the regulation of uNK cell function and the maintenance of normal pregnancy ${ }^{235}$ as galectin-9, secreted by human trophoblast cells, induces the transformation of peripheral NK cells into uNK-like cells via the interaction with TIM-3. In addition, a decreased number of 
TIM- $3+$ uNK cells was detected in human miscarriages and abortion-prone murine models, and a Th2/Th1 imbalance was detected in TIM- $3+$ uNK cells in human and mouse miscarriages, suggesting the importance of the galectin-9/TIM-3 pathway. ${ }^{235}$ Moreover, Treg cells increase their galectin-9 expression with advancing gestational age in accord with the increasing galectin-9 concentrations in maternal blood, suggesting that galectin-9 expressing Treg cells may have important roles in the maintenance of pregnancy. ${ }^{236}$

\section{Galectins in placental angiogenesis}

Aside from modulating the immune system and trophoblast invasion, human galectins have been implicated in key roles in angiogenesis (Fig. 3). This is not surprising in light of the pivotal role of galectin-glycan interactions in angiogenesis ${ }^{237}$ and the angiostimulatory roles of several galectins reviewed elsewhere. ${ }^{14}$ The most studied galectin, with respect to placental angiogenesis, is galectin-1. When this lectin is added exogeneously in a rodent model of reduced angiogenesis, it enhances the production of pro-angiogenic factors (e.g. angiogenin, heparin-binding epidermal growth factor, and fibroblast growth factor-basic) and matrix metallopeptidases (MMP-3, MMP-8, and MMP-9) to promote normal vascular development, to rescue implantation and to support healthy placentation. ${ }^{238}$ Galectin-1 acts via the NRP-1-VEGF-VEGF-R2 signaling pathway, ${ }^{239,240}$ which is important in promoting angiogenesis during implantation, decidualization and placentation. ${ }^{241,242}$ Galectin-1 binding to neuropilin-1 promotes VEGF-VEGF-R2 interactions, and consequently, endothelial cell migration and adhesion, ${ }^{239,241,243}$ and these effects can be blocked by an NRP-1 neutralizing antibody, which inhibits VEGF-VEGF-R2 signaling. ${ }^{238,240}$

Although several other galectins (-3, -8, and -9) have been implicated in angiogenesis and endothelial cell biology, ${ }^{14}$ their involvement in placental angiogenesis has not yet been elucidated. The effect of galectin-13 has recently been tested on rat vasculature, and it was found that recombinant galectin- 13 reduces blood pressure and increases utero-placental perfusion in vivo, while it promotes vasodilation in isolated arteries in vitro. ${ }^{24,245}$

\section{Galectins in local inflammation in the womb}

Term parturition is characterized by local pro-inflammatory changes in the decidua and chorioamnion, which play fundamental roles in the initiation of labor and myometrial contractions. ${ }^{37,246-249}$ Evidence from microarray studies have shown that galectins may also play a role in pathways leading to term labor as galectin-7 is up-regulated in the amnion in oxytocin-induced labor, and galectin-9 is down-regulated in the chorion at the site of rupture (Fig. 4). ${ }^{37}$

Preterm parturition is a syndrome that has many etiologies, predominantly those associated with intra-amniotic infection and inflammation. ${ }^{193,205,250}$ The pathways initiated in preterm parturition are different from those in term labor, whereas the terminal pathway of cervical effacement and dilatation, choriodecidual, as well as myometrial activation, are shared between the two. ${ }^{193,205,246,250}$ Interestingly, proteomics studies show that galectin- 1 is upregulated in the fetal membranes in preterm parturition, ${ }^{38}$ reflecting heightened local inflammation.

Preterm premature rupture of the membranes (PPROM) is a syndrome in which approximately $32 \%-75 \%$ of the cases are associated with microbial invasion of the amniotic cavity. ${ }^{193,195,196}$ To date, only galectin-1 expression has been studied in PPROM using detailed gene and protein expression profiling, ${ }^{34}$ it is increased in the chorioamniotic membranes in patients with histologic chorioamnionitis, but not in those without this condition. Galectin-1 expression is increased ${ }^{34}$ in a temporal and spatial fashion in amnion epithelial cells, maternal neutrophils and chorioamniotic macrophages and myofibroblasts ${ }^{251}$ with advancing inflammation. Since galectin-1 is associated with the up-regulation of genes encoding for MMPs in DCs, ${ }^{252}$ it has been proposed that the overexpression of galectin-1 in the chorioamniotic membranes may be the link between inflammation, tissue remodeling, and membrane weakening, which may contribute to the membrane rupture. ${ }^{34}$ Moreover, the increased expression of galectin-1 by chorioamniotic macrophages upon inflammation suggests a role for galectin- 1 in the active barrier functions of the membranes, protecting the fetus from bacterial infection and promoting the recognition and phagocytic removal of invading maternal neutrophils. ${ }^{34}$ This hypothesis is supported by findings that (1) activated macrophages are present in the fetal membranes in association with fetal inflammatory response upon infection, ${ }^{253-255}$ (2) the chorioamniotic membranes have antimicrobial properties, ${ }^{256}$ (3) galectin-1 expression is up-regulated in activated macrophages ${ }^{257}$ where it regulates macrophage effector functions, ${ }^{258}$ (4) galectin-1 decreases macrophage inducible nitric oxide synthase expression and inhibits lipopolysaccharideinduced NO metabolism, ${ }^{259}$ and (5) it regulates the cell surface expression of Fc $\gamma$ RI. ${ }^{258}$

\section{Galectins in inflammatory conditions in the neonate}

Due to galectins' roles in immune responses, their relevant roles in term and preterm parturition in the neonate have also been investigated, mainly regarding galectin- 1 and galectin- 3 


\section{Chorioamniotic membranes}

Galectin-1

$\uparrow$ Chorioamnionitis

$\uparrow$ Preterm parturition

Galectin-9

$\downarrow$ Membrane rupture
Galectin-7

$\uparrow$ Oxytocin induced labor
Fetus / Neonate

Galectin-3

$\uparrow$ Bacterial infection

$\uparrow$ Birth asphyxia

$\uparrow$ Small-for-gestational age

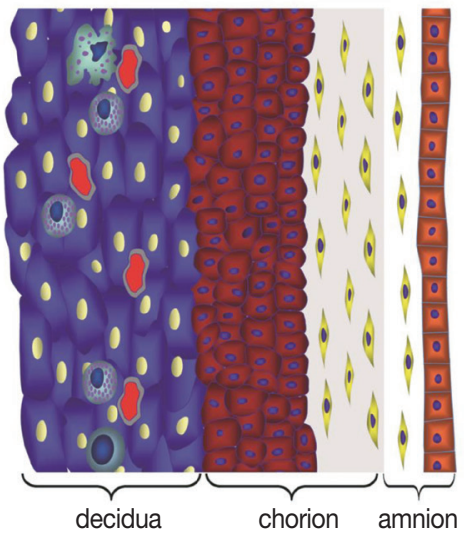

Maternal blood

$$
\begin{array}{ll}
\cline { 1 - 1 } \text { Galectin-1 } & \text { Galectin-13 } \\
\downarrow \text { Early-onset } & \downarrow \text { Preterm preeclampsia } \\
\text { preeclampsia } & \downarrow \text { Intrauterine growth restriction } \\
& \downarrow \text { Preterm labor }
\end{array}
$$

Villous placenta

Galectin-1

$\uparrow$ Severe preeclampsia

$\downarrow$ Early-onset preeclampsia

Galectin-8

$\uparrow$ Severe preeclampsia

$\uparrow$ HELLP sy.

$\downarrow$ Preterm labor
Galectin-13

$\uparrow$ Shedding in preterm preeclampsia/HELLP sy.

$\downarrow$ Preterm preeclampsia

$\downarrow$ Preterm HELLP sy.

Galectin-14

$\downarrow$ Preterm preeclampsia

Fig. 4. Galectin expression at the maternal-fetal interface. The figure represents the maternal-fetal interfaces where maternal and fetal cells appose each other from the end of the first trimester of human pregnancy. The villous syncytiotrophoblast (depicted with gold) is bathed in maternal blood, whereas invasive extravillous trophoblasts in the placental bed (depicted in red) and chorionic trophoblasts in the fetal membranes (depicted in red) are in contact with maternal cells in the decidua (depicted in dark blue). The differential expression of galectins is depicted according to the interface where observed in normal pregnancy and in pregnancy complications. Sy., syndrome, Cartoon was adapted from Than et al. Trends Endocrinol Metab 2012; 23: 23-31, with permission of Elsevier. ${ }^{16}$

(Fig. 4). ${ }^{260-262}$

In term parturition, in spite of the physiological systemic inflammation in the mother at the time of normal delivery, cord blood plasma contains more galectin-3 than maternal plasma, regardless of the delivery mode. ${ }^{262}$ In addition, cord blood neutrophils show priming in comparison to maternal neutrophils by responding to galectin-3 with reactive oxygen species (ROS) production, suggesting that inflammatory stimuli associated with labor promotes neutrophils to develop a reactive phenotype with extensive priming features. ${ }^{262}$ Indeed, when cord blood leukocytes are stimulated by invasive bacteria, there is an induction of galectin-3 expression, suggesting its importance for innate immunity in the neonate. ${ }^{260}$ Although galectin- 1 is also expressed in cord blood, lymphocytes expressing galectin-1 were not determined to have a major role in immune reactivity in cord blood. ${ }^{263}$

In preterm parturition, the earlier preterm birth occurs, the higher the rate of intra-amniotic infection and inflammation. ${ }^{193}$
Since $5 \%-13 \%$ of pregnancies are affected by preterm parturition, ${ }^{194}$ the resulting severe complications (i.e. intraventricular hemorrhage, cystic periventricular leukomalacia, bronchopulmonary dysplasia [BPD], and cerebral palsy) have disastrous short-term and life-long impacts on the neonate, and the healthcare and social impacts are immense. ${ }^{193,205}$ In regard to these, galectin-3 concentrations are elevated in the cerebrospinal fluid of infants suffering from birth asphyxia, and even higher in those with abnormal outcomes. ${ }^{261}$ Since galectin- 3 is produced by activated microglia/macrophages and activates NADPH oxidase, leading to neurotoxic production of ROS and contributing to hypoxic brain injury in an animal model, ${ }^{264}$ it has been proposed to serve as a marker for abnormal outcomes. ${ }^{261}$ In addition, in a small preliminary study, galectin-3 concentrations in tracheal aspirates of premature infants tended to be elevated in the first week of life in those who later developed BPD (Staretz et al., personal communication). 
IUGR is one of the most heterogeneous syndromes in obstetrics; it is associated with fetal malformations and chromosomal abnormalities, as well as maternal autoimmune disorders and placental dysfunction resulting from poor implantation, making the understanding of an IUGR fetus a challenge. In addition, neonates may be small-for-gestational age (SGA) due to a normal condition in short-stature couples. ${ }^{265}$ Of interest, a recent report showed that galectin- 3 concentrations in cord blood have a positive correlation with gestational age, and SGA neonates have higher concentrations of galectin- 3 than those that are appropriate for gestational age ${ }^{260}$ which may be a sign of an inflammatory condition.

\section{Galectins in preeclampsia, a systemic inflammatory state}

Based on the above data, it is not surprising that galectins have been implicated in the development of preeclampsia, a syndrome with impaired trophoblast invasion, an anti-angiogenic state and an exaggerated maternal systemic immune response. ${ }^{190,266}$ Preeclampsia is a severe complication of pregnancy, which affects $5 \%-7 \%$ of pregnant women and is a leading cause of maternal and perinatal morbidity and mortality. ${ }^{267,268}$ It also confers a high risk to the mother and fetus for metabolic and cardiovascular diseases later in life. ${ }^{269-272}$ Preeclampsia is a syndrome with a spectrum of phenotypes, which may present at various gestational ages, with different degrees of severity at clinical onset, and also with or without the involvement of the fetus. ${ }^{272-274}$

It is a multi-stage disease that has placental origins ${ }^{190,275-277}$ due to the failure of extravillous trophoblast invasion into the uterine tissues $^{278,279}$ and impaired villous trophoblastic syncytialization. ${ }^{72,280,281}$ Subsequent rheological changes in uterine blood flow, metabolic changes, and ischemic stress of the villous placenta lead to the liberation of anti-angiogenic molecules, highly inflammatory placental debris, and cell-free fetal DNA that may also be pro-inflammatory and cause an exaggerated maternal systemic inflammatory response, anti-angiogenic conditions and end-organ damage. ${ }^{179,181,190,192,271,275-277,282-291}$ Other, less severe pathologies are also implicated that result in the terminal pathway of systemic inflammation and an anti-angiogenic state. ${ }^{292}$ Importantly, several members of the galectin family have been implicated in the development of various stages of this syndrome (Fig. 4).

\section{Impaired extravillous trophoblast invasion}

Indirect evidence of galectin involvement is the up-regulation of galectin- 1 and -3 in the extravillous trophoblasts in the placental bed during preeclampsia and HELLP syndrome, ${ }^{38,158}$ which is associated with the failure of extravillous trophoblast invasion. ${ }^{32}$ It was also observed that low galectin-13 expression is associated with deficient trophoblast invasion, failure of spiral arteriole conversion, and the development of preeclampsia. ${ }^{28}$

\section{Impaired villous trophoblastic syncytialization}

Galectin-13 and galectin-14 mRNA expression is decreased in the syncytiotrophoblast in preeclampsia associated with or without HELLP syndrome at the time of clinical onset, predominantly in the early-onset forms. ${ }^{28,33,72}$ Importantly, decreased galectin-13 mRNA expression can be detected as early as the first trimester in laser captured specimens of chorionic villous trophoblasts as well as decreased galectin-13 protein and mRNA concentrations in first trimester maternal serum sampled from patients destined to develop preeclampsia. ${ }^{36}$ This phenomenon possibly reflects abnormal villous trophoblast syncytialization starting from early pregnancy and may be one of the earliest placental indicators for the subsequent development of preeclampsia. A recent study ${ }^{72}$ revealed that GCM1 and ESRRG, two transcription factors that regulate villous trophoblastic syncytialization and metabolic functions, are down-regulated in the placenta in preeclampsia. Functional and evolutionary evidence also implicates these two factors in regulating trophoblastic expression of chromosome 19 galectin cluster genes. This is supported by the observation of decreased GCM1-mediated trophoblast fusion in impaired galectin gene expression in preeclampsia. ${ }^{72}$ Furthermore, the differential methylation of LGALS13 and LGALS14 is also found in the villous trophoblast in preterm preeclampsia, suggesting that potential additional disease-mechanisms may account for the trophoblastic pathology in preterm preeclampsia. ${ }^{72}$

\section{Villous placental stress}

Galectin- 1 and -8 are overexpressed in the villous trophoblast in preeclampsia and HELLP syndrome, ${ }^{32,35}$ where increased placental stress occurs preceding exaggerated maternal systemic inflammation. ${ }^{275,276,290,293,294}$ It is possible that galectins may function as "alarmins" in this condition. ${ }^{12,35}$ Alarmins are endogenous danger signals secreted by activated cells via non-classical pathways or released from necrotic cells, which signal tissue damage and contribute to the activation and/or resolution of immune responses. ${ }^{66}$ Galectin-13 may also be considered a placental alarmin since it is excessively secreted or shed from the syncytiotrophoblast at the time of the clinical onset of preeclampsia and HELLP syndrome. ${ }^{33,64}$ Interestingly, the syncytiotrophoblast microvillous membrane and microvesicles, which are shed from the 
syncytiotrophoblast, stain strongly for galectin-13, suggesting that the increased release of galectin-13-positive microvesicles from the syncytiotrophoblast may lead to elevated maternal serum galectin- 13 concentrations when the clinical symptoms appear. $^{33,46}$

\section{Anti-angiogenesis}

Placental and maternal blood galectin-1 expression is downregulated in patients with early-onset preeclampsia, and Lgals1 $\mathrm{KO}$ mice exhibit preeclampsia-like symptoms, probably due to the inhibition of pro-angiogenic effects of galectin- $1 .{ }^{238}$ Moreover, blocking galectin-1-mediated angiogenesis with anginex, a synthetic peptide, also promotes preeclampsia-like symptoms in mice and inhibits human extravillous trophoblast functions in vitro. ${ }^{238,295}$

\section{Maternal systemic inflammation}

The number of galectin-1-expressing NK cells and Treg cells is decreased in preeclampsia, ${ }^{51,296,297}$ which may reflect a failure of immune tolerance in this syndrome. ${ }^{298}$ Recently, the involvement of galectin- 9 and its TIM- 3 ligand has been implicated in maternal systemic inflammation in preeclampsia. ${ }^{299}$ In this regard, decreased TIM-3 expression by T cells, cytotoxic T cells, NK cells, and CD56dim NK cells, as well as increased frequency of galectin-9+ peripheral lymphocytes, is detected in women with early-onset preeclampsia, suggesting that the impairment of the galectin-9/TIM-3 pathway can result in an enhanced systemic inflammatory response including the activation of Th1 lymphocytes in preeclampsia. ${ }^{299}$

\section{Galectins implicated as maternal blood biomarkers in obstetrical syndromes}

Due to the dysregulation of some galectins at the maternal-fetal interface and in maternal blood in various obstetrical syndromes, investigations have been expanded on their possible value as diagnostic, predictive and prognostic biomarkers of these pregnancy complications. Most data is available for galectin-13, also known as PP13, which has been widely investigated by international collaborative studies (Fig. 4). ${ }^{41-50,58}$ The changes in the expression patterns of galectin-13 in the placenta during gestation in normal and preeclamptic pregnancies, the fact that galectin-13 is expressed only in the placenta, ${ }^{27}$ and it is not detected in non-pregnant patients (Madar-Shapiro et al., personal communication), make this galectin a suitable and promising first trimester maternal blood biomarker for the prediction of preterm preeclampsia. In addition, genetic studies found certain single nucleotide polymorphisms, including an exonic variant
(221delT) in the LGALS13 gene, which may increase the risk for preterm labor and preeclampsia. ${ }^{300}$ Recent advancement in the field has also facilitated the study of the potential use of this galectin as a therapeutic drug for preeclampsia. ${ }^{24,245}$ The utilization of other galectins as biomarkers has recently been started.

In the first trimester of pregnancy, there is a lower PP13 mRNA content in maternal blood in preeclampsia compared to controls; ${ }^{301,302}$ however, the predictive value of the detected maternal blood PP13 mRNA species is currently limited due to the varying and low amounts of trophoblastic mRNA reaching the maternal circulation. Much more promising results were derived from studies on maternal blood PP13 concentrations in the first trimester for the prediction of preeclampsia, which were analyzed by a recent meta-analysis. ${ }^{303}$ The results were pooled from 19 studies on singleton pregnancies, which were included in prospective or nested case-control studies or fully prospective studies in which a total of 16,153 pregnant women were tested for PP13 between 6 and 14 weeks of gestation. ${ }^{42-48,50,58,304-313}$ For all cases of preeclampsia, the mean detection rate (DR) for predicting preeclampsia was $47 \%$ (95\% confidence interval [CI], 43 to 65 ) at a $10 \%$ false-positive rate (FPR). For preterm preeclampsia, the DR was $66 \%$ (95\% CI, 48 to 78); for early-onset preeclampsia, the DR was $83 \%$ (95\% CI, 25 to 100). For all cases of preeclampsia, the positive likelihood ratio (LR) [sensitivity/ (1-specificity)] was 5.82, while the negative LR [(1-sensitivity)/ specificity] was 0.46 . For preterm preeclampsia, both of these indices were better (positive LR, 6.94; negative LR, 0.34).

Of interest, the introduction of maternal ABO blood groups into the prediction model could improve the DRs for preeclampsia, which can be explained by the differential binding of PP13 onto ABO blood group antigen-containing cell surfaces and the varying bioavailability of PP13 in maternal blood depending on the $\mathrm{ABO}$ blood type. ${ }^{58}$ Moreover, the performance of the first trimester PP13 test could further be improved by the inclusion of PP13 into panels of multiple biomarkers (e.g. ADAM metallopeptidase domain 12 [ADAM12], pregnancy associated plasma protein A [PAPP-A], placenta growth factor [PIGF] $],{ }^{50,314}$ which is necessitated in light of the syndromic nature of preeclampsia. ${ }^{48,314}$ In addition, risk predictions based on combining PP13 and uterine artery Doppler pulsatility index (PI) also showed increased prediction accuracy. ${ }^{42,44,304,306,314-316}$ Moreover, the combination of PP13, Doppler PI, and maternal artery stiffness (MAP) increased the DR of preeclampsia to $93 \%$ for early-onset preeclampsia and to $86 \%$ for all cases of preeclampsia at $10 \% \mathrm{FPR}^{49}$ This is in line with comprehensive risk algorithms based on combined multi-marker analysis of back- 
ground risks, MAP, Doppler PI, and a panel of blood biomarkers that can yield much higher predictive value and accuracy than individual markers, ${ }^{306}$ especially for early-onset ( $<34$ weeks) and preterm $(<37$ weeks) preeclampsia. Therefore, the introduction of a broad biomarker panel for the evaluation of preeclampsia and other obstetrical syndromes in the first trimester is suggested in order to change antenatal care as formulated by the inverted pyramid model of perinatal evaluation in pregnancy. ${ }^{317}$

In the second trimester of pregnancy, galectin-13 does not have much diagnostic or predictive value due to the sharp increase in PP13 maternal blood concentrations in preeclampsia between the first and third trimesters compared to the moderate change in women with normal pregnancy. ${ }^{318}$ Interestingly, galectin-1 has recently emerged as a potential preclinical biomarker for preeclampsia since a prospective study detected decreased galectin-1 maternal blood concentrations and placental expression in early-onset preeclampsia compared to normal pregnancy in mid pregnancy. ${ }^{238}$ Of note, placental galectin-1 expression is increased in preterm and severe preeclampsia compared to normal pregnancy. 35,238

In the third trimester of pregnancy, galectin-13 may have diagnostic significance for the clinical development of preeclampsia according to a recent meta-analysis. ${ }^{318}$ This included eight clinical studies that contained third trimester maternal blood PP13 data from 2750 pregnant women. ${ }^{33,45,46,58,319,320}$ Maternal blood PP13 was higher in women who subsequently developed preeclampsia compared to unaffected women. The mean DR at 10\% FPR for all preeclampsia cases was 59.4\% (95\% CI, 49.7 to 64.5$)$, and for preterm preeclampsia was $71.7 \%(95 \% \mathrm{CI}$, 60.3 to 75.3$)$. Interestingly, the DR appeared to be related to the severity of the cases in a given study, showing that the higher the hypertension and proteinuria, the higher the third trimester PP13 in maternal blood. A combined algorithm of PP13, MAP and proteinuria yielded a 95\% DR for preterm preeclampsia and $85 \%$ for all preeclampsia at 5\% FPR. The positive LR for all cases of preeclampsia was 5.94 and the negative LR was 0.45 , providing an overall LR of 26.24. The positive LR for preterm preeclampsia was 7.17 and the negative LR was 0.31 , providing an overall LR of 37.99. Therefore, the meta-analysis indicates that higher third trimester maternal blood PP13, among women who subsequently developed preeclampsia, reached clinical diagnostic levels. ${ }^{318}$

\section{CONCLUSION}

Galectins are an evolutionarily ancient family of lectins that have pleiotropic functions in the regulation of key biological processes. Galectins are pivotal in immune responses, angiogenesis, cell migration and invasion, and due to these functions, they have double-edged functions in shared and unique pathways of embryonic and tumor development. Recent advances facilitate the use of galectins as biomarkers in obstetrical syndromes and in various malignancies, and their therapeutic applications are also under investigation.

\section{Conflicts of Interest}

No potential conflict of interest relevant to this article was reported.

\section{Acknowledgments}

We thank Szilvia Szabo, Zsolt Gelencser and Balint Peterfia (Hungarian Academy of Sciences), Krisztian Papp (Eotvos Lorand University), Pat Schoff and Russ Price (Perinatology Research Branch), and Valerie Richardson (Yale University) for their technical assistance and/or art work, and Sara Tipton (Wayne State University) for critical reading of the manuscript. Figs. 1 and 4 were adapted from reference 16 with kind permission from Elsevier. Fig. 3 was adapted from reference 217 under the terms of the Creative Commons Attribution License and with kind permission from Martin Knofler and Jurgen Pollheimer. Original research conducted by the authors in the topic and the writing of this manuscript was supported, in part, by the Perinatology Research Branch, Division of Intramural Research, Eunice Kennedy Shriver National Institute of Child Health and Human Development (NICHD), National Institutes of Health (NIH), Department of Health and Human Services (DHHS); Federal funds from the NICHD under Contract No. HHSN275201300006C; the European Union FP6 Grant "Pregenesys 037244”; the Hungarian OTKA-PD Grant “104398”; and the Hungarian Academy of Sciences Momentum Grant "LP2014-7/2014".

\section{REFERENCES}

1. Apweiler R, Hermjakob H, Sharon N. On the frequency of protein glycosylation, as deduced from analysis of the SWISS-PROT database. Biochim Biophys Acta 1999; 1473: 4-8.

2. Gabius HJ, André S, Kaltner H, Siebert HC. The sugar code: functional lectinomics. Biochim Biophys Acta 2002; 1572: 165-77.

3. Varki A, Cummings RD, Esko JD, et al. Essentials in glycobiology. Cold Spring Harbor: Cold Spring Harbor Laboratory Press, 2008.

4. Barondes SH. Bifunctional properties of lectins: lectins redefined. 
Trends Biochem Sci 1988; 13: 480-2.

5. Hirabayashi J, Kasai K. The family of metazoan metal-independent beta-galactoside-binding lectins: structure, function and molecular evolution. Glycobiology 1993; 3: 297-304.

6. Barondes SH, Cooper DN, Gitt MA, Leffler H. Galectins. Structure and function of a large family of animal lectins. J Biol Chem 1994; 269: 20807-10.

7. Kasai K, Hirabayashi J. Galectins: a family of animal lectins that decipher glycocodes. J Biochem 1996; 119: 1-8.

8. Cummings RD, Liu FT. Galectins. In: Varki A, Cummings R, Esko JD, et al., eds. Essentials of glycobiology. 2nd ed. Cold Spring Harbor: Cold Spring Harbor Laboratory Press, 2009; 475-88.

9. Cooper DN. Galectinomics: finding themes in complexity. Biochim Biophys Acta 2002; 1572: 209-31.

10. Blois SM, Ilarregui JM, Tometten $\mathrm{M}$, et al. A pivotal role for galectin-1 in fetomaternal tolerance. Nat Med 2007; 13: 1450-7.

11. Rabinovich GA, Toscano MA. Turning 'sweet' on immunity: galectin-glycan interactions in immune tolerance and inflammation. Nat Rev Immunol 2009; 9: 338-52.

12. Sato S, St-Pierre C, Bhaumik P, Nieminen J. Galectins in innate immunity: dual functions of host soluble beta-galactoside-binding lectins as damage-associated molecular patterns (DAMPs) and as receptors for pathogen-associated molecular patterns (PAMPs). Immunol Rev 2009; 230: 172-87.

13. Liu FT, Rabinovich GA. Galectins: regulators of acute and chronic inflammation. Ann N Y Acad Sci 2010; 1183: 158-82.

14. Blois SM, Conrad ML, Freitag N, Barrientos G. Galectins in angiogenesis: consequences for gestation. J Reprod Immunol 2015; 108: 33-41.

15. Griffioen AW, Thijssen VL. Galectins in tumor angiogenesis. Ann Transl Med 2014; 2: 90.

16. Than NG, Romero R, Kim CJ, McGowen MR, Papp Z, Wildman DE. Galectins: guardians of eutherian pregnancy at the maternalfetal interface. Trends Endocrinol Metab 2012; 23: 23-31.

17. Blidner AG, Rabinovich GA. 'Sweetening' pregnancy: galectins at the fetomaternal interface. Am J Reprod Immunol 2013; 69: 369-82.

18. Choe YS, Shim C, Choi D, Lee CS, Lee KK, Kim K. Expression of galectin-1 mRNA in the mouse uterus is under the control of ovarian steroids during blastocyst implantation. Mol Reprod Dev 1997; 48: 261-6.

19. Vicovac L, Janković M, Cuperlović M. Galectin-1 and -3 in cells of the first trimester placental bed. Hum Reprod 1998; 13: 730-5.

20. Koopman LA, Kopcow HD, Rybalov B, et al. Human decidual natural killer cells are a unique NK cell subset with immunomodulatory potential. J Exp Med 2003; 198: 1201-12.

21. Popovici RM, Krause MS, Germeyer A, Strowitzki T, von Wolff M.
Galectin-9: a new endometrial epithelial marker for the mid- and late-secretory and decidual phases in humans. J Clin Endocrinol Metab 2005; 90: 6170-6.

22. von Wolff M, Wang X, Gabius HJ, Strowitzki T. Galectin fingerprinting in human endometrium and decidua during the menstrual cycle and in early gestation. Mol Hum Reprod 2005; 11: 189-94.

23. Liu AX, Jin F, Zhang WW, et al. Proteomic analysis on the alteration of protein expression in the placental villous tissue of early pregnancy loss. Biol Reprod 2006; 75: 414-20.

24. Lewis SK, Farmer JL, Burghardt RC, et al. Galectin 15 (LGALS15): a gene uniquely expressed in the uteri of sheep and goats that functions in trophoblast attachment. Biol Reprod 2007; 77: 1027-36.

25. Kopcow HD, Rosetti F, Leung Y, Allan DS, Kutok JL, Strominger JL. T Cell apoptosis at the maternal-fetal interface in early human pregnancy, involvement of galectin-1. Proc Natl Acad Sci U S A 2008; 105: 18472-7.

26. Than NG, Romero R, Erez O, et al. Emergence of hormonal and redox regulation of galectin-1 in placental mammals: implication in maternal-fetal immune tolerance. Proc Natl Acad Sci U S A 2008; 105: 15819-24.

27. Than NG, Romero R, Goodman M, et al. A primate subfamily of galectins expressed at the maternal-fetal interface that promote immune cell death. Proc Natl Acad Sci U S A 2009; 106: 9731-6.

28. Kliman HJ, Sammar M, Grimpel YI, et al. Placental protein 13 and decidual zones of necrosis: an immunologic diversion that may be linked to preeclampsia. Reprod Sci 2012; 19: 16-30.

29. Than NG, Sumegi B, Than GN, Berente Z, Bohn H. Isolation and sequence analysis of a cDNA encoding human placental tissue protein 13 (PP13), a new lysophospholipase, homologue of human eosinophil Charcot-Leyden Crystal protein. Placenta 1999; 20: 703-10.

30. Bozić M, Petronijević M, Milenković S, Atanacković J, Lazić J, Vicovać L. Galectin-1 and galectin-3 in the trophoblast of the gestational trophoblastic disease. Placenta 2004; 25: 797-802.

31. Than NG, Pick E, Bellyei S, et al. Functional analyses of placental protein 13/galectin-13. Eur J Biochem 2004; 271: 1065-78.

32. Jeschke U, Mayr D, Schiessl B, et al. Expression of galectin-1, -3 (gal1, gal-3) and the Thomsen-Friedenreich (TF) antigen in normal, IUGR, preeclamptic and HELLP placentas. Placenta 2007; 28: 1165-73.

33. Than NG, Abdul Rahman O, Magenheim R, et al. Placental protein 13 (galectin-13) has decreased placental expression but increased shedding and maternal serum concentrations in patients presenting with preterm pre-eclampsia and HELLP syndrome. Virchows Arch 2008; 453: 387-400.

34. Than NG, Kim SS, Abbas A, et al. Chorioamnionitis and increased galectin-1 expression in PPROM: an anti-inflammatory response 
in the fetal membranes? Am J Reprod Immunol 2008; 60: 298-311.

35. Than NG, Erez O, Wildman DE, et al. Severe preeclampsia is characterized by increased placental expression of galectin-1. J Matern Fetal Neonatal Med 2008; 21: 429-42.

36. Sekizawa A, Purwosunu Y, Yoshimura S, et al. PP13 mRNA expression in trophoblasts from preelamptic placentas. Reprod Sci 2009; 16: 408-13.

37. Nhan-Chang CL, Romero R, Tarca AL, et al. Characterization of the transcriptome of chorioamniotic membranes at the site of rupture in spontaneous labor at term. Am J Obstet Gynecol 2010; 202: 462.e1-41.

38. Shankar R, Johnson MP, Williamson NA, et al. Molecular markers of preterm labor in the choriodecidua. Reprod Sci 2010; 17: 297-310.

39. Kolundžić N, Bojić-Trbojević Z, Radojćić L, Petronijević M, Vićovac L. Galectin- 8 is expressed by villous and extravillous trophoblast of the human placenta. Placenta 2011; 32: 909-11.

40. Houzelstein D, Goncalves IR, Fadden AJ, et al. Phylogenetic analysis of the vertebrate galectin family. Mol Biol Evol 2004; 21: 1177-87.

41. Burger O, Pick E, Zwickel J, et al. Placental protein 13 (PP-13): effects on cultured trophoblasts, and its detection in human body fluids in normal and pathological pregnancies. Placenta 2004; 25: 608-22.

42. Nicolaides KH, Bindra R, Turan OM, et al. A novel approach to firsttrimester screening for early pre-eclampsia combining serum PP-13 and Doppler ultrasound. Ultrasound Obstet Gynecol 2006; 27: $13-7$.

43. Chafetz I, Kuhnreich I, Sammar M, et al. First-trimester placental protein 13 screening for preeclampsia and intrauterine growth restriction. Am J Obstet Gynecol 2007; 197: 35.e1-7.

44. Spencer K, Cowans NJ, Chefetz I, Tal J, Meiri H. First-trimester maternal serum PP-13, PAPP-A and second-trimester uterine artery Doppler pulsatility index as markers of pre-eclampsia. Ultrasound Obstet Gynecol 2007; 29: 128-34.

45. Gonen R, Shahar R, Grimpel YI, et al. Placental protein 13 as an early marker for pre-eclampsia: a prospective longitudinal study. BJOG 2008; 115: 1465-72.

46. Huppertz B, Sammar M, Chefetz I, Neumaier-Wagner P, Bartz C, Meiri H. Longitudinal determination of serum placental protein 13 during development of preeclampsia. Fetal Diagn Ther 2008; 24: 230-6.

47. Romero R, Kusanovic JP, Than NG, et al. First-trimester maternal serum PP13 in the risk assessment for preeclampsia. Am J Obstet Gynecol 2008; 199: 122.e1-11.

48. Akolekar R, Syngelaki A, Beta J, Kocylowski R, Nicolaides KH. Maternal serum placental protein 13 at 11-13 weeks of gestation in preeclampsia. Prenat Diagn 2009; 29: 1103-8.

49. Khalil A, Cowans NJ, Spencer K, Goichman S, Meiri H, Harrington $\mathrm{K}$. First-trimester markers for the prediction of pre-eclampsia in women with a-priori high risk. Ultrasound Obstet Gynecol 2010;
35: 671-9.

50. Wortelboer EJ, Koster MP, Cuckle HS, Stoutenbeek PH, Schielen PC, Visser GH. First-trimester placental protein 13 and placental growth factor: markers for identification of women destined to develop early-onset pre-eclampsia. BJOG 2010; 117: 1384-9.

51. Molvarec A, Blois SM, Stenczer B, et al. Peripheral blood galectin1-expressing $\mathrm{T}$ and natural killer cells in normal pregnancy and preeclampsia. Clin Immunol 2011; 139: 48-56.

52. Brewer FC. Binding and cross-linking properties of galectins. Biochim Biophys Acta 2002; 1572: 255-62.

53. Swaminathan GJ, Leonidas DD, Savage MP, Ackerman SJ, Acharya KR. Selective recognition of mannose by the human eosinophil Charcot-Leyden crystal protein (galectin-10): a crystallographic study at 1.8 Å resolution. Biochemistry 1999; 38: 13837-43.

54. Visegrády B, Than NG, Kilár F, Sümegi B, Than GN, Bohn H. Homology modelling and molecular dynamics studies of human placental tissue protein 13 (galectin-13). Protein Eng 2001; 14: 875-80.

55. López-Lucendo MF, Soliś D, André S, et al. Growth-regulatory human galectin-1: crystallographic characterisation of the structural changes induced by single-site mutations and their impact on the thermodynamics of ligand binding. J Mol Biol 2004; 343: 957-70.

56. Horlacher T, Oberli MA, Werz DB, et al. Determination of carbohydrate-binding preferences of human galectins with carbohydrate microarrays. Chembiochem 2010; 11: 1563-73.

57. Stowell SR, Arthur CM, Dias-Baruffi M, et al. Innate immune lectins kill bacteria expressing blood group antigen. Nat Med 2010; 16: 295-301.

58. Than NG, Romero R, Meiri H, et al. PP13, maternal ABO blood groups and the risk assessment of pregnancy complications. PLoS One 2011; 6: e21564.

59. Liu FT, Patterson RJ, Wang JL. Intracellular functions of galectins. Biochim Biophys Acta 2002; 1572: 263-73.

60. Camby I, Le Mercier M, Lefranc F, Kiss R. Galectin-1: a small protein with major functions. Glycobiology 2006; 16: 137R-57R.

61. Nickel W. Unconventional secretory routes: direct protein export across the plasma membrane of mammalian cells. Traffic 2005; 6 : 607-14.

62. Danielsen EM, Hansen GH. Lipid raft organization and function in brush borders of epithelial cells. Mol Membr Biol 2006; 23: 71-9.

63. Hernandez JD, Baum LG. Ah, sweet mystery of death! Galectins and control of cell fate. Glycobiology 2002; 12: 127R-36R.

64. Balogh A, Pozsgay J, Matkó J, et al. Placental protein 13 (PP13/galectin-13) undergoes lipid raft-associated subcellular redistribution in the syncytiotrophoblast in preterm preeclampsia and HELLP syndrome. Am J Obstet Gynecol 2011; 205: 156.e1-14.

65. Dennis JW, Nabi IR, Demetriou M. Metabolism, cell surface orga- 
nization, and disease. Cell 2009; 139: 1229-41.

66. Bianchi ME. DAMPs, PAMPs and alarmins: all we need to know about danger. J Leukoc Biol 2007; 81: 1-5.

67. Su AI, Wiltshire T, Batalov S, et al. A gene atlas of the mouse and human protein-encoding transcriptomes. Proc Natl Acad Sci U S A 2004; 101: 6062-7.

68. Saal I, Nagy N, Lensch M, et al. Human galectin-2: expression profiling by RT-PCR/immunohistochemistry and its introduction as a histochemical tool for ligand localization. Histol Histopathol 2005; 20: 1191-208.

69. Dong M, Ding G, Zhou J, Wang H, Zhao Y, Huang H. The effect of trophoblasts on T lymphocytes: possible regulatory effector molecules: a proteomic analysis. Cell Physiol Biochem 2008; 21: 463-72.

70. Kubach J, Lutter P, Bopp T, et al. Human CD4+CD25+ regulatory T cells: proteome analysis identifies galectin- 10 as a novel marker essential for their anergy and suppressive function. Blood 2007; 110: $1550-8$.

71. Yang QS, Ying K, Yuan HL, et al. Cloning and expression of a novel human galectin cDNA, predominantly expressed in placenta. Biochim Biophys Acta 2002; 1574: 407-11.

72. Than NG, Romero R, Xu Y, et al. Evolutionary origins of the placental expression of chromosome 19 cluster galectins and their complex dysregulation in preeclampsia. Placenta 2014; 35: 855-65.

73. Vasta GR. Roles of galectins in infection. Nat Rev Microbiol 2009; 7: 424-38.

74. John CM, Jarvis GA, Swanson KV, et al. Galectin-3 binds lactosaminylated lipooligosaccharides from Neisseria gonorrhoeae and is selectively expressed by mucosal epithelial cells that are infected. Cell Microbiol 2002; 4: 649-62.

75. Rabinovich GA, Gruppi A. Galectins as immunoregulators during infectious processes: from microbial invasion to the resolution of the disease. Parasite Immunol 2005; 27: 103-14.

76. Kasamatsu A, Uzawa K, Shimada K, et al. Elevation of galectin-9 as an inflammatory response in the periodontal ligament cells exposed to Porphylomonas gingivalis lipopolysaccharide in vitro and in vivo. Int J Biochem Cell Biol 2005; 37: 397-408.

77. Ouellet M, Mercier S, Pelletier I, et al. Galectin-1 acts as a soluble host factor that promotes HIV-1 infectivity through stabilization of virus attachment to host cells. J Immunol 2005; 174: 4120-6.

78. Fowler M, Thomas RJ, Atherton J, Roberts IS, High NJ. Galectin-3 binds to Helicobacter pylori O-antigen: it is upregulated and rapidly secreted by gastric epithelial cells in response to $\mathrm{H}$. pylori adhesion. Cell Microbiol 2006; 8: 44-54.

79. Gauthier S, Pelletier I, Ouellet M, et al. Induction of galectin-1 expression by HTLV-I Tax and its impact on HTLV-I infectivity. Retrovirology 2008; 5: 105.
80. Okumura CY, Baum LG, Johnson PJ. Galectin-1 on cervical epithelial cells is a receptor for the sexually transmitted human parasite Trichomonas vaginalis. Cell Microbiol 2008; 10: 2078-90.

81. Fichorova RN. Impact of T. vaginalis infection on innate immune responses and reproductive outcome. J Reprod Immunol 2009; 83: 185-9.

82. Hepojoki J, Strandin T, Hetzel U, et al. Acute hantavirus infection induces galectin-3-binding protein. J Gen Virol 2014; 95(Pt 11): 235664.

83. Varki A. Nothing in glycobiology makes sense, except in the light of evolution. Cell 2006; 126: 841-5.

84. Mercier S, St-Pierre C, Pelletier I, Ouellet M, Tremblay MJ, Sato S. Galectin-1 promotes HIV-1 infectivity in macrophages through stabilization of viral adsorption. Virology 2008; 371: 121-9.

85. Kim HR, Lin HM, Biliran H, Raz A. Cell cycle arrest and inhibition of anoikis by galectin-3 in human breast epithelial cells. Cancer Res 1999; 59: 4148-54.

86. Ryan CM, Mehlert A, Richardson JM, Ferguson MA, Johnson PJ. Chemical structure of Trichomonas vaginalis surface lipoglycan: a role for short galactose (beta1-4/3) N-acetylglucosamine repeats in host cell interaction. J Biol Chem 2011; 286: 40494-508.

87. Smith LM, Wang M, Zangwill K, Yeh S. Trichomonas vaginalis infection in a premature newborn. J Perinatol 2002; 22: 502-3.

88. Sato S, Ouellet N, Pelletier I, Simard M, Rancourt A, Bergeron MG. Role of galectin-3 as an adhesion molecule for neutrophil extravasation during streptococcal pneumonia. J Immunol 2002; 168: 1813-22.

89. Lebovic DI, Mueller MD, Taylor RN. Immunobiology of endometriosis. Fertil Steril 2001; 75: 1-10.

90. Omwandho CO, Konrad L, Halis G, Oehmke F, Tinneberg HR. Role of TGF-betas in normal human endometrium and endometriosis. Hum Reprod 2010; 25: 101-9.

91. Noël JC, Chapron C, Borghese B, Fayt I, Anaf V. Galectin-3 is overexpressed in various forms of endometriosis. Appl Immunohistochem Mol Morphol 2011; 19: 253-7.

92. Bastón JI, Barañao RI, Ricci AG, et al. Targeting galectin-1-induced angiogenesis mitigates the severity of endometriosis. J Pathol 2014; 234: 329-37.

93. Caserta D, Di Benedetto L, Bordi G, D’Ambrosio A, Moscarini M. Levels of galectin- 3 and stimulation expressed gene 2 in the peritoneal fluid of women with endometriosis: a pilot study. Gynecol Endocrinol 2014; 30: 877-80.

94. Vergetaki A, Jeschke U, Vrekoussis T, et al. Galectin-1 overexpression in endometriosis and its regulation by neuropeptides $(\mathrm{CRH}$, $\mathrm{UCN}$ ) indicating its important role in reproduction and inflammation. PLoS One 2014; 9: e114229. 
95. Chen HL, Liao F, Lin TN, Liu FT. Galectins and neuroinflammation. Adv Neurobiol 2014; 9: 517-42.

96. Borghese B, Vaiman D, Mondon F, et al. Neurotrophins and pain in endometriosis. Gynecol Obstet Fertil 2010; 38: 442-6.

97. Ebrahim AH, Alalawi Z, Mirandola L, et al. Galectins in cancer: carcinogenesis, diagnosis and therapy. Ann Transl Med 2014; 2: 88.

98. Jeschke U, Hutter S, Heublein S, et al. Expression and function of galectins in the endometrium and at the human feto-maternal interface. Placenta 2013; 34: 863-72.

99. Jung EJ, Moon HG, Cho BI, et al. Galectin-1 expression in cancerassociated stromal cells correlates tumor invasiveness and tumor progression in breast cancer. Int J Cancer 2007; 120: 2331-8.

100. Moiseeva EV, Rapoport EM, Bovin NV, et al. Galectins as markers of aggressiveness of mouse mammary carcinoma: towards a lectin target therapy of human breast cancer. Breast Cancer Res Treat 2005; 91: 227-41.

101. Ferrer CM, Reginato MJ. Sticking to sugars at the metastatic site: sialyltransferase ST6GalNAc2 acts as a breast cancer metastasis suppressor. Cancer Discov 2014; 4: 275-7.

102. van den Brule FA, Buicu C, Berchuck A, et al. Expression of the 67$\mathrm{kD}$ laminin receptor, galectin-1, and galectin-3 in advanced human uterine adenocarcinoma. Hum Pathol 1996; 27: 1185-91.

103. Ege CB, Akbulut M, Zekioğlu O, Ozdemir N. Investigation of galectin-3 and heparanase in endometrioid and serous carcinomas of the endometrium and correlation with known predictors of survival. Arch Gynecol Obstet 2011; 284: 1231-9.

104. Dalotto-Moreno T, Croci DO, Cerliani JP, et al. Targeting galectin-1 overcomes breast cancer-associated immunosuppression and prevents metastatic disease. Cancer Res 2013; 73: 1107-17.

105. van den Brule F, Califice S, Garnier F, Fernandez PL, Berchuck A, Castronovo V. Galectin-1 accumulation in the ovary carcinoma peritumoral stroma is induced by ovary carcinoma cells and affects both cancer cell proliferation and adhesion to laminin- 1 and fibronectin. Lab Invest 2003; 83: 377-86.

106. Kohrenhagen N, Volker HU, Kapp M, Dietl J, Kammerer U. Increased expression of galectin-1 during the progression of cervical neoplasia. Int J Gynecol Cancer 2006; 16: 2018-22.

107. Kim HJ, Do IG, Jeon HK, et al. Galectin 1 expression is associated with tumor invasion and metastasis in stage IB to IIA cervical cancer. Hum Pathol 2013; 44: 62-8.

108. Huang EY, Chanchien CC, Lin H, Wang CC, Wang CJ, Huang CC. Galectin-1 is an independent prognostic factor for local recurrence and survival after definitive radiation therapy for patients with squamous cell carcinoma of the uterine cervix. Int J Radiat Oncol Biol Phys 2013; 87: 975-82.

109. Huang EY, Chen YF, Chen YM, et al. A novel radioresistant mecha- nism of galectin-1 mediated by H-Ras-dependent pathways in cervical cancer cells. Cell Death Dis 2012; 3: e251.

110. Lee JW, Song SY, Choi JJ, et al. Decreased galectin-3 expression during the progression of cervical neoplasia. J Cancer Res Clin Oncol 2006; $132:$ 241-7.

111. Logullo AF, Lopes AB, Nonogaki S, et al. C-erbB-2 expression is a better predictor for survival than galectin-3 or p53 in early-stage breast cancer. Oncol Rep 2007; 18: 121-6.

112. Stewart CJ, Crook ML. Galectin-3 expression in uterine endometrioid adenocarcinoma: comparison of staining in conventional tumor glands and in areas of MELF pattern myometrial invasion. Int J Gynecol Pathol 2010; 29: 555-61.

113. Brustmann H, Riss D, Naudé S. Galectin-3 expression in normal, hyperplastic, and neoplastic endometrial tissues. Pathol Res Pract 2003; 199: 151-8.

114. Oishi T, Itamochi H, Kigawa J, et al. Galectin-3 may contribute to cisplatin resistance in clear cell carcinoma of the ovary. Int J Gynecol Cancer 2007; 17: 1040-6.

115. Kim MK, Sung CO, Do IG, et al. Overexpression of galectin-3 and its clinical significance in ovarian carcinoma. Int J Clin Oncol 2011; 16: $352-8$

116. Min KW, Park MH, Hong SR, et al. Clear cell carcinomas of the ovary: a multi-institutional study of 129 cases in Korea with prognostic significance of Emi1 and galectin-3. Int J Gynecol Pathol 2013; 32: 3-14.

117. Lee JH, Zhang X, Shin BK, Lee ES, Kim I. Mac-2 binding protein and galectin-3 expression in mucinous tumours of the ovary: an annealing control primer system and immunohistochemical study. Pathology 2009; 41: 229-33.

118. Dagher SF, Wang JL, Patterson RJ. Identification of galectin-3 as a factor in pre-mRNA splicing. Proc Natl Acad Sci U S A 1995; 92: 1213-7.

119. Honjo Y, Nangia-Makker P, Inohara H, Raz A. Down-regulation of galectin-3 suppresses tumorigenicity of human breast carcinoma cells. Clin Cancer Res 2001; 7: 661-8.

120. Dumic J, Dabelic S, Flögel M. Galectin-3: an open-ended story. Biochim Biophys Acta 2006; 1760: 616-35.

121. Baptiste TA, James A, Saria M, Ochieng J. Mechano-transduction mediated secretion and uptake of galectin-3 in breast carcinoma cells: implications in the extracellular functions of the lectin. Exp Cell Res 2007; 313: 652-64.

122. Yang RY, Hsu DK, Liu FT. Expression of galectin-3 modulates T-cell growth and apoptosis. Proc Natl Acad Sci U S A 1996; 93: 6737-42.

123. Akahani S, Nangia-Makker P, Inohara H, Kim HR, Raz A. Galectin-3: a novel antiapoptotic molecule with a functional BH1 (NWGR) domain of Bcl-2 family. Cancer Res 1997; 57: 5272-6. 
124. Matarrese P, Tinari N, Semeraro ML, Natoli C, Iacobelli S, Malorni W. Galectin-3 overexpression protects from cell damage and death by influencing mitochondrial homeostasis. FEBS Lett 2000; 473: 311-5.

125. Moon BK, Lee YJ, Battle P, Jessup JM, Raz A, Kim HR. Galectin-3 protects human breast carcinoma cells against nitric oxide-induced apoptosis: implication of galectin-3 function during metastasis. Am J Pathol 2001; 159: 1055-60.

126. Lin HM, Pestell RG, Raz A, Kim HR. Galectin-3 enhances cyclin D (1) promoter activity through SP1 and a cAMP-responsive element in human breast epithelial cells. Oncogene 2002; 21: 8001-10.

127. Yu F, Finley RL Jr, Raz A, Kim HR. Galectin-3 translocates to the perinuclear membranes and inhibits cytochrome $\mathrm{c}$ release from the mitochondria: a role for synexin in galectin-3 translocation. J Biol Chem 2002; 277: 15819-27.

128. Choi JH, Chun KH, Raz A, Lotan R. Inhibition of N-(4-hydroxyphenyl)retinamide-induced apoptosis in breast cancer cells by galectin-3. Cancer Biol Ther 2004; 3: 447-52.

129. Nangia-Makker P, Raz T, Tait L, Hogan V, Fridman R, Raz A. Galectin-3 cleavage: a novel surrogate marker for matrix metalloproteinase activity in growing breast cancers. Cancer Res 2007; 67: 11760-8.

130. Balan V, Nangia-Makker P, Raz A. Galectins as cancer biomarkers. Cancers (Basel) 2010; 2: 592-610.

131. Mazurek N, Byrd JC, Sun Y, Ueno S, Bresalier RS. A galectin-3 sequence polymorphism confers TRAIL sensitivity to human breast cancer cells. Cancer 2011; 117: 4375-80.

132. Mazurek N, Sun YJ, Liu KF, et al. Phosphorylated galectin-3 mediates tumor necrosis factor-related apoptosis-inducing ligand signaling by regulating phosphatase and tensin homologue deleted on chromosome 10 in human breast carcinoma cells. J Biol Chem 2007; 282: 21337-48.

133. Guha P, Bandyopadhyaya G, Polumuri SK, et al. Nicotine promotes apoptosis resistance of breast cancer cells and enrichment of side population cells with cancer stem cell-like properties via a signaling cascade involving galectin-3, alpha9 nicotinic acetylcholine receptor and STAT3. Breast Cancer Res Treat 2014; 145: 5-22.

134. Tsai CJ, Sulman EP, Eifel PJ, et al. Galectin-7 levels predict radiation response in squamous cell carcinoma of the cervix. Gynecol Oncol 2013; 131: 645-9.

135. Ueda S, Kuwabara I, Liu FT. Suppression of tumor growth by galectin-7 gene transfer. Cancer Res 2004; 64: 5672-6.

136. Saussez S, Kiss R. Galectin-7. Cell Mol Life Sci 2006; 63: 686-97.

137. Matsui Y, Ueda S, Watanabe J, Kuwabara I, Ogawa O, Nishiyama H. Sensitizing effect of galectin-7 in urothelial cancer to cisplatin through the accumulation of intracellular reactive oxygen species.
Cancer Res 2007; 67: 1212-20.

138. St-Pierre Y, Campion CG, Grosset AA. A distinctive role for galectin-7 in cancer? Front Biosci (Landmark Ed) 2012; 17: 438-50.

139. Grosset AA, Labrie M, Gagné D, et al. Cytosolic galectin-7 impairs p53 functions and induces chemoresistance in breast cancer cells. BMC Cancer 2014; 14: 801.

140. Campion CG, Labrie M, Lavoie G, St-Pierre Y. Expression of galectin-7 is induced in breast cancer cells by mutant p53. PLoS One 2013; 8: e72468.

141. Lahm H, Andre S, Hoeflich A, et al. Tumor galectinology: insights into the complex network of a family of endogenous lectins. Glycoconj J 2004; 20: 227-38.

142. Danguy A, Rorive S, Decaestecker C, et al. Immunohistochemical profile of galectin- 8 expression in benign and malignant tumors of epithelial, mesenchymatous and adipous origins, and of the nervous system. Histol Histopathol 2001; 16: 861-8.

143. Liang MY, Lu YM, Zhang Y, Zhang SL. Serum galectin-9 in cervical cancer. Zhonghua Yi Xue Za Zhi 2008; 88: 2783-5.

144. Liang $\mathrm{CH}$, Wu CY. Glycan array: a powerful tool for glycomics studies. Expert Rev Proteomics 2009; 6: 631-45.

145. Irie A, Yamauchi A, Kontani K, et al. Galectin-9 as a prognostic factor with antimetastatic potential in breast cancer. Clin Cancer Res 2005; $11: 2962-8$.

146. Heusschen R, Griffioen AW, Thijssen VL. Galectin-9 in tumor biology: a jack of multiple trades. Biochim Biophys Acta 2013; 1836: 177-85.

147. Mylonas I, Mayr D, Walzel H, et al. Mucin 1, Thomsen-Friedenreich expression and galectin-1 binding in endometrioid adenocarcinoma: an immunohistochemical analysis. Anticancer Res 2007; 27: 1975-80.

148. Khaldoyanidi SK, Glinsky VV, Sikora L, et al. MDA-MB-435 human breast carcinoma cell homo- and heterotypic adhesion under flow conditions is mediated in part by Thomsen-Friedenreich antigen-galectin-3 interactions. J Biol Chem 2003; 278: 4127-34.

149. Yu LG, Andrews N, Zhao Q, et al. Galectin-3 interaction with Thomsen-Friedenreich disaccharide on cancer-associated MUC1 causes increased cancer cell endothelial adhesion. J Biol Chem 2007; 282: 773-81.

150. Inohara H, Akahani S, Raz A. Galectin-3 stimulates cell proliferation. Exp Cell Res 1998; 245: 294-302.

151. Song L, Tang JW, Owusu L, Sun MZ, Wu J, Zhang J. Galectin-3 in cancer. Clin Chim Acta 2014; 431: 185-91.

152. Zhu H, Wu TC, Chen WQ, et al. Roles of galectin-7 and S100A9 in cervical squamous carcinoma: Clinicopathological and in vitro evidence. Int J Cancer 2013; 132: 1051-9.

153. Park JE, Chang WY, Cho M. Induction of matrix metalloprotein- 
ase-9 by galectin-7 through p38 MAPK signaling in HeLa human cervical epithelial adenocarcinoma cells. Oncol Rep 2009; 22: 1373-9.

154. Labrie M, Vladoiu MC, Grosset AA, Gaboury L, St-Pierre Y. Expression and functions of galectin-7 in ovarian cancer. Oncotarget 2014; 5: 7705-21.

155. Demers M, Rose AA, Grosset AA, et al. Overexpression of galectin-7, a myoepithelial cell marker, enhances spontaneous metastasis of breast cancer cells. Am J Pathol 2010; 176: 3023-31.

156. Liu J, Cheng Y, He M, Yao S. Vascular endothelial growth factor C enhances cervical cancer cell invasiveness via upregulation of galectin-3 protein. Gynecol Endocrinol 2014; 30: 461-5.

157. Nangia-Makker P, Wang Y, Raz T, et al. Cleavage of galectin-3 by matrix metalloproteases induces angiogenesis in breast cancer. Int J Cancer 2010; 127: 2530-41.

158. Liu FT, Rabinovich GA. Galectins as modulators of tumour progression. Nat Rev Cancer 2005; 5: 29-41.

159. Chen C, Duckworth CA, Fu B, Pritchard DM, Rhodes JM, Yu LG. Circulating galectins $-2,-4$ and -8 in cancer patients make important contributions to the increased circulation of several cytokines and chemokines that promote angiogenesis and metastasis. Br J Cancer 2014; 110: 741-52.

160. Fridman WH, Pagès F, Sautès-Fridman C, Galon J. The immune contexture in human tumours: impact on clinical outcome. Nat Rev Cancer 2012; 12: 298-306.

161. Toscano MA, Bianco GA, Ilarregui JM, et al. Differential glycosylation of TH1, TH2 and TH-17 effector cells selectively regulates susceptibility to cell death. Nat Immunol 2007; 8: 825-34.

162. Li H, Wang Y, Zhou F. Effect of ex vivo-expanded $\gamma \delta$-T cells combined with galectin-1 antibody on the growth of human cervical cancer xenografts in SCID mice. Clin Invest Med 2010; 33: E280-9.

163. Rabinovich GA. Galectin-1 as a potential cancer target. Br J Cancer 2005; 92: 1188-92.

164. Fukumori T, Takenaka Y, Yoshii T, et al. CD29 and CD7 mediate galectin-3-induced type II T-cell apoptosis. Cancer Res 2003; 63: 8302-11.

165. Iurisci I, Tinari N, Natoli C, Angelucci D, Cianchetti E, Iacobelli S. Concentrations of galectin-3 in the sera of normal controls and cancer patients. Clin Cancer Res 2000; 6: 1389-93.

166. Barrow H, Guo X, Wandall HH, et al. Serum galectin-2, -4 , and -8 are greatly increased in colon and breast cancer patients and promote cancer cell adhesion to blood vascular endothelium. Clin Cancer Res 2011; 17: 7035-46.

167. Carlsson MC, Balog CI, Kilsgård O, et al. Different fractions of human serum glycoproteins bind galectin-1 or galectin-8, and their ratio may provide a refined biomarker for pathophysiological conditions in cancer and inflammatory disease. Biochim Biophys Acta 2012; 1820: 1366-72.
168. Balasubramanian K, Vasudevamurthy R, Venkateshaiah SU, Thomas A, Vishweshwara A, Dharmesh SM. Galectin-3 in urine of cancer patients: stage and tissue specificity. J Cancer Res Clin Oncol 2009; 135: 355-63.

169. Jerzak M, Bischof P. Apoptosis in the first trimester human placenta: the role in maintaining immune privilege at the maternalfoetal interface and in the trophoblast remodelling. Eur J Obstet Gynecol Reprod Biol 2002; 100: 138-42.

170. Petty HR, Kindzelskii AL, Espinoza J, Romero R. Trophoblast contact deactivates human neutrophils. J Immunol 2006; 176: 3205-14.

171. Moffett A, Loke C. Immunology of placentation in eutherian mammals. Nat Rev Immunol 2006; 6: 584-94.

172. Erlebacher A. Immune surveillance of the maternal/fetal interface: controversies and implications. Trends Endocrinol Metab 2010; 21: 428-34.

173. Mor G, Cardenas I. The immune system in pregnancy: a unique complexity. Am J Reprod Immunol 2010; 63: 425-33.

174. Arck PC, Hecher K. Fetomaternal immune cross-talk and its consequences for maternal and offspring's health. Nat Med 2013; 19: $548-56$.

175. Bianchi DW. Current knowledge about fetal blood cells in the maternal circulation. J Perinat Med 1998; 26: 175-85.

176. Nelson JL. Pregnancy, persistent microchimerism, and autoimmune disease. J Am Med Womens Assoc 1998; 53: 31-2, 47.

177. Lapaire O, Hösli I, Zanetti-Daellenbach R, et al. Impact of fetalmaternal microchimerism on women's health: a review. J Matern Fetal Neonatal Med 2007; 20: 1-5.

178. Redman CW, Sargent IL. Microparticles and immunomodulation in pregnancy and pre-eclampsia. J Reprod Immunol 2007; 76: 61-7.

179. Redman CW, Sargent IL. Circulating microparticles in normal pregnancy and pre-eclampsia. Placenta 2008; 29 Suppl A: S73-7.

180. Naccasha N, Gervasi MT, Chaiworapongsa T, et al. Phenotypic and metabolic characteristics of monocytes and granulocytes in normal pregnancy and maternal infection. Am J Obstet Gynecol 2001; 185: 1118-23.

181. Hahn S, Giaglis S, Hoesli I, Hasler P. Neutrophil NETs in reproduction: from infertility to preeclampsia and the possibility of fetal loss. Front Immunol 2012; 3: 362.

182. Redman CW, Sacks GP, Sargent IL. Preeclampsia: an excessive maternal inflammatory response to pregnancy. Am J Obstet Gynecol 1999; 180(2 Pt 1): 499-506.

183. Gervasi MT, Chaiworapongsa T, Pacora P, et al. Phenotypic and metabolic characteristics of monocytes and granulocytes in preeclampsia. Am J Obstet Gynecol 2001; 185: 792-7.

184. Gervasi MT, Chaiworapongsa T, Naccasha N, et al. Phenotypic and metabolic characteristics of maternal monocytes and granulo- 
cytes in preterm labor with intact membranes. Am J Obstet Gynecol 2001; 185: 1124-9.

185. Gervasi MT, Chaiworapongsa T, Naccasha N, et al. Maternal intravascular inflammation in preterm premature rupture of membranes. J Matern Fetal Neonatal Med 2002; 11: 171-5.

186. Ogge G, Romero R, Chaiworapongsa T, et al. Leukocytes of pregnant women with small-for-gestational age neonates have a different phenotypic and metabolic activity from those of women with preeclampsia. J Matern Fetal Neonatal Med 2010; 23: 476-87.

187. Aluvihare VR, Kallikourdis M, Betz AG. Regulatory T cells mediate maternal tolerance to the fetus. Nat Immunol 2004; 5: 266-71.

188. Wildman DE, Chen C, Erez O, Grossman LI, Goodman M, Romero R. Evolution of the mammalian placenta revealed by phylogenetic analysis. Proc Natl Acad Sci U S A 2006; 103: 3203-8.

189. Aplin JD. Developmental cell biology of human villous trophoblast: current research problems. Int J Dev Biol 2010; 54: 323-9.

190. Redman CW, Sargent IL. Immunology of pre-eclampsia. Am J Reprod Immunol 2010; 63: 534-43.

191. Romero R. Prenatal medicine: the child is the father of the man. 1996. J Matern Fetal Nonatal Med 2009; 22: 636-9.

192. Redman CW, Sargent IL. Latest advances in understanding preeclampsia. Science 2005; 308: 1592-4.

193. Romero R, Espinoza J, Kusanovic JP, et al. The preterm parturition syndrome. BJOG 2006; 113 Suppl 3: 17-42.

194. Goldenberg RL, Culhane JF, Iams JD, Romero R. Epidemiology and causes of preterm birth. Lancet 2008; 371: 75-84.

195. DiGiulio DB, Romero R, Amogan HP, et al. Microbial prevalence, diversity and abundance in amniotic fluid during preterm labor: a molecular and culture-based investigation. PLoS One 2008; 3: e3056.

196. Kim MJ, Romero R, Gervasi MT, et al. Widespread microbial invasion of the chorioamniotic membranes is a consequence and not a cause of intra-amniotic infection. Lab Invest 2009; 89: 924-36.

197. Kim CJ, Romero R, Kusanovic JP, et al. The frequency, clinical significance, and pathological features of chronic chorioamnionitis: a lesion associated with spontaneous preterm birth. Mod Pathol 2010; 23: 1000-11.

198. Ogge G, Romero R, Lee DC, et al. Chronic chorioamnionitis displays distinct alterations of the amniotic fluid proteome. J Pathol 2011; 223: 553-65.

199. Lee J, Romero R, Xu Y, et al. A signature of maternal anti-fetal rejection in spontaneous preterm birth: chronic chorioamnionitis, anti-human leukocyte antigen antibodies, and C4d. PLoS One 2011; 6: e16806.

200. Lee J, Romero R, Xu Y, et al. Maternal HLA panel-reactive antibodies in early gestation positively correlate with chronic chorioamni- onitis: evidence in support of the chronic nature of maternal anti-fetal rejection. Am J Reprod Immunol 2011; 66: 510-26.

201. Xu Y, Tarquini F, Romero R, et al. Peripheral CD300a+CD8+ T lymphocytes with a distinct cytotoxic molecular signature increase in pregnant women with chronic chorioamnionitis. Am J Reprod Immunol 2012; 67: 184-97.

202. Lee J, Romero R, Chaiworapongsa T, et al. Characterization of the fetal blood transcriptome and proteome in maternal anti-fetal rejection: evidence of a distinct and novel type of human fetal systemic inflammatory response. Am J Reprod Immunol 2013; 70: 265-84.

203. Lee J, Romero R, Xu Y, et al. Detection of anti-HLA antibodies in maternal blood in the second trimester to identify patients at risk of antibody-mediated maternal anti-fetal rejection and spontaneous preterm delivery. Am J Reprod Immunol 2013; 70: 162-75.

204. Romero R, Miranda J, Chaiworapongsa T, et al. Prevalence and clinical significance of sterile intra-amniotic inflammation in patients with preterm labor and intact membranes. Am J Reprod Immunol 2014; 72: 458-74.

205. Romero R, Dey SK, Fisher SJ. Preterm labor: one syndrome, many causes. Science 2014; 345: 760-5.

206. Colnot C, Fowlis D, Ripoche MA, Bouchaert I, Poirier F. Embryonic implantation in galectin 1 /galectin 3 double mutant mice. Dev Dyn 1998; 211: 306-13.

207. Walzel H, Neels P, Bremer H, et al. Immunohistochemical and glycohistochemical localization of the beta-galactoside-binding Stype lectin in human placenta. Acta Histochem 1995; 97: 33-42.

208. van den Brule FA, Fernandez PL, Buicu C, et al. Differential expression of galectin-1 and galectin-3 during first trimester human embryogenesis. Dev Dyn 1997; 209: 399-405.

209. Kolundžić N, Bojić-Trbojević Ž, Kovačević T, Stefanoska I, Kadoya T, Vićovac L. Galectin-1 is part of human trophoblast invasion machinery: a functional study in vitro. PLoS One 2011; 6: e28514.

210. Arikawa T, Simamura E, Shimada H, et al. Expression pattern of Galectin 4 in rat placentation. Placenta 2012; 33: 885-7.

211. Than GN, Bohn H, Szabo DG. Advances in pregnancy-related protein research: functional and clinical applications. Boca Raton: CRC Press, 1993.

212. Bischof $\mathrm{P}$, Irminger-Finger I. The human cytotrophoblastic cell, a mononuclear chameleon. Int J Biochem Cell Biol 2005; 37: 1-16.

213. Ahmed MS, Aleksunes LM, Boeuf P, et al. IFPA Meeting 2012 Workshop Report II: epigenetics and imprinting in the placenta, growth factors and villous trophoblast differentiation, role of the placenta in regulating fetal exposure to xenobiotics during pregnancy, infection and the placenta. Placenta 2013; 34 Suppl: S6-10.

214. Chiariotti L, Salvatore P, Frunzio R, Bruni CB. Galectin genes: reg- 
ulation of expression. Glycoconj J 2004; 19: 441-9.

215. Segerer S, Kammerer U, Kapp M, Dietl J, Rieger L. Upregulation of chemokine and cytokine production during pregnancy. Gynecol Obstet Invest 2009; 67: 145-50.

216. Hammer A. Immunological regulation of trophoblast invasion. J Reprod Immunol 2011; 90: 21-8.

217. Knöfler M, Pollheimer J. Human placental trophoblast invasion and differentiation: a particular focus on Wnt signaling. Front Genet 2013; 4: 190 .

218. Lima PD, Zhang J, Dunk C, Lye SJ, Croy BA. Leukocyte driven-decidual angiogenesis in early pregnancy. Cell Mol Immunol 2014; 11: 522-37.

219. Godbole G, Suman P, Gupta SK, Modi D. Decidualized endometrial stromal cell derived factors promote trophoblast invasion. Fertil Steril 2011; 95: 1278-83.

220. Phillips B, Knisley K, Weitlauf KD, Dorsett J, Lee V, Weitlauf H. Differential expression of two beta-galactoside-binding lectins in the reproductive tracts of pregnant mice. Biol Reprod 1996; 55: 548-58.

221. Lee VH, Lee AB, Phillips EB, Roberts JK, Weitlauf HM. Spatiotemporal pattern for expression of galectin-3 in the murine uteroplacental complex: evidence for differential regulation. Biol Reprod 1998; 58: 1277-82.

222. Yang H, Lei C, Zhang W. Expression of galectin-3 in mouse endometrium and its effect during embryo implantation. Reprod Biomed Online 2012; 24: 116-22.

223. Shimizu Y, Kabir-Salmani M, Azadbakht M, Sugihara K, Sakai K, Iwashita M. Expression and localization of galectin-9 in the human uterodome. Endocr J 2008; 55: 879-87.

224. Yang H, Lei CX, Zhang W. Human chorionic gonadotropin (hCG) regulation of galectin-3 expression in endometrial epithelial cells and endometrial stromal cells. Acta Histochem 2013; 115: 3-7.

225. Blois SM, Barrientos G. Galectin signature in normal pregnancy and preeclampsia. J Reprod Immunol 2014; 101-102: 127-34.

226. Tirado-González I, Freitag N, Barrientos G, et al. Galectin-1 influences trophoblast immune evasion and emerges as a predictive factor for the outcome of pregnancy. Mol Hum Reprod 2013; 19: 43-53.

227. Heusschen R, Freitag N, Tirado-González I, et al. Profiling Lgals9 splice variant expression at the fetal-maternal interface: implications in normal and pathological human pregnancy. Biol Reprod 2013; 88: 22.

228. Knöfler M, Pollheimer J. IFPA Award in Placentology lecture: molecular regulation of human trophoblast invasion. Placenta 2012; 33 Suppl: S55-62.

229. Elola MT, Chiesa ME, Alberti AF, Mordoh J, Fink NE. Galectin-1 receptors in different cell types. J Biomed Sci 2005; 12: 13-29.

230. Crider-Pirkle S, Billingsley P, Faust C, Hardy DM, Lee V, Weitlauf
H. Cubilin, a binding partner for galectin-3 in the murine utero-placental complex. J Biol Chem 2002; 277: 15904-12.

231. Garin MI, Chu CC, Golshayan D, Cernuda-Morollon E, Wait R, Lechler RI. Galectin-1: a key effector of regulation mediated by CD4+CD25+ T cells. Blood 2007; 109: 2058-65.

232. Karimi K, Arck PC. Natural killer cells: keepers of pregnancy in the turnstile of the environment. Brain Behav Immun 2010; 24: 339-47.

233. Zhu C, Anderson AC, Schubart A, et al. The Tim-3 ligand galectin-9 negatively regulates T helper type 1 immunity. Nat Immunol 2005; 6: 1245-52.

234. Wang F, Wan L, Zhang C, Zheng X, Li J, Chen ZK. Tim-3-Galectin-9 pathway involves the suppression induced by CD4+CD25+ regulatory T cells. Immunobiology 2009; 214: 342-9.

235. Li YH, Zhou WH, Tao Y, et al. The galectin-9/Tim-3 pathway is involved in the regulation of NK cell function at the maternal-fetal interface in early pregnancy. Cell Mol Immunol 2015 Jan 12 [Epub]. http://dx.doi.org/10.1038/cmi.2014.126.

236. Meggyes M, Miko E, Polgar B, et al. Peripheral blood TIM-3 positive NK and CD8+ T cells throughout pregnancy: TIM-3/galectin-9 interaction and its possible role during pregnancy. PLoS One 2014; 9: e92371.

237. Nangia-Makker P, Baccarini S, Raz A. Carbohydrate-recognition and angiogenesis. Cancer Metastasis Rev 2000; 19: 51-7.

238. Freitag N, Tirado-González I, Barrientos G, et al. Interfering with Gal-1-mediated angiogenesis contributes to the pathogenesis of preeclampsia. Proc Natl Acad Sci U S A 2013; 110: 11451-6.

239. Hsieh SH, Ying NW, Wu MH, et al. Galectin-1, a novel ligand of neuropilin-1, activates VEGFR-2 signaling and modulates the migration of vascular endothelial cells. Oncogene 2008; 27: 3746-53.

240. Douglas NC, Tang H, Gomez R, et al. Vascular endothelial growth factor receptor 2 (VEGFR-2) functions to promote uterine decidual angiogenesis during early pregnancy in the mouse. Endocrinology 2009; 150: 3845-54.

241. Halder JB, Zhao X, Soker S, et al. Differential expression of VEGF isoforms and $\operatorname{VEGF(164)-specific~receptor~neuropilin-1~in~the~}$ mouse uterus suggests a role for VEGF(164) in vascular permeability and angiogenesis during implantation. Genesis 2000; 26: 213-24.

242. Baston-Buest DM, Porn AC, Schanz A, Kruessel JS, Janni W, Hess AP. Expression of the vascular endothelial growth factor receptor neuropilin-1 at the human embryo-maternal interface. Eur J Obstet Gynecol Reprod Biol 2011; 154: 151-6.

243. Soker S, Takashima S, Miao HQ, Neufeld G, Klagsbrun M. Neuropilin-1 is expressed by endothelial and tumor cells as an isoformspecific receptor for vascular endothelial growth factor. Cell 1998; 92: 735-45.

244. Gizurarson S, Huppertz B, Osol G, Skarphedinsson JO, Mandala 
M, Meiri H. Effects of placental protein 13 on the cardiovascular system in gravid and non-gravid rodents. Fetal Diagn Ther 2013; 33: 257-64.

245. Sammar M, Nisamblatt S, Gonen R, et al. The role of the carbohydrate recognition domain of placental protein 13 (PP13) in pregnancy evaluated with recombinant PP13 and the DelT221 PP13 variant. PLoS One 2014; 9: e102832.

246. Romero R, Espinoza J, Gonçalves LF, Kusanovic JP, Friel LA, Nien JK. Inflammation in preterm and term labour and delivery. Semin Fetal Neonatal Med 2006; 11: 317-26.

247. Hassan SS, Romero R, Tarca AL, et al. The transcriptome of cervical ripening in human pregnancy before the onset of labor at term: identification of novel molecular functions involved in this process. J Matern Fetal Neonatal Med 2009; 22: 1183-93.

248. Hassan SS, Romero R, Tarca AL, et al. The molecular basis for sonographic cervical shortening at term: identification of differentially expressed genes and the epithelial-mesenchymal transition as a function of cervical length. Am J Obstet Gynecol 2010; 203: 472.e1-14.

249. Mittal P, Romero R, Tarca AL, et al. Characterization of the myometrial transcriptome and biological pathways of spontaneous human labor at term. J Perinat Med 2010; 38: 617-43.

250. Romero R, Mazor M, Munoz H, Gomez R, Galasso M, Sherer DM. The preterm labor syndrome. Ann N Y Acad Sci 1994; 734: 414-29.

251. Kim SS, Romero R, Kim JS, et al. Coexpression of myofibroblast and macrophage markers: novel evidence for an in vivo plasticity of chorioamniotic mesodermal cells of the human placenta. Lab Invest 2008; 88: 365-74.

252. Fulcher JA, Hashimi ST, Levroney EL, et al. Galectin-1-matured human monocyte-derived dendritic cells have enhanced migration through extracellular matrix. J Immunol 2006; 177: 216-26.

253. Sutton L, Mason DY, Redman CW. HLA-DR positive cells in the human placenta. Immunology 1983; 49: 103-12.

254. Eis AL, Brockman DE, Myatt L. Immunolocalization of the inducible nitric oxide synthase isoform in human fetal membranes. Am J Reprod Immunol 1997; 38: 289-94.

255. Benirschke K, Kaufmann P, Baergen RN. Pathology of the human placenta. 5th ed. New York: Springer-Verlag, 2006.

256. Espinoza J, Chaiworapongsa T, Romero R, et al. Antimicrobial peptides in amniotic fluid: defensins, calprotectin and bacterial/permeability-increasing protein in patients with microbial invasion of the amniotic cavity, intra-amniotic inflammation, preterm labor and premature rupture of membranes. J Matern Fetal Neonatal Med 2003; 13: 2-21.

257. Gil CD, Cooper D, Rosignoli G, Perretti M, Oliani SM. Inflammation-induced modulation of cellular galectin- 1 and -3 expression in a model of rat peritonitis. Inflamm Res 2006; 55: 99-107.
258. Barrionuevo P, Beigier-Bompadre M, Ilarregui JM, et al. A novel function for galectin-1 at the crossroad of innate and adaptive immunity: galectin-1 regulates monocyte/macrophage physiology through a nonapoptotic ERK-dependent pathway. J Immunol 2007; 178: 436-45.

259. Correa SG, Sotomayor CE, Aoki MP, Maldonado CA, Rabinovich GA. Opposite effects of galectin-1 on alternative metabolic pathways of L-arginine in resident, inflammatory, and activated macrophages. Glycobiology 2003; 13: 119-28.

260. Demmert M, Faust K, Bohlmann MK, et al. Galectin-3 in cord blood of term and preterm infants. Clin Exp Immunol 2012; 167: 246-51.

261. Savman K, Heyes MP, Svedin P, Karlsson A. Microglia/macrophage-derived inflammatory mediators galectin-3 and quinolinic acid are elevated in cerebrospinal fluid from newborn infants after birth asphyxia. Transl Stroke Res 2013; 4: 228-35.

262. Sundqvist M, Osla V, Jacobsson B, Rudin A, Sävman K, Karlsson A. Cord blood neutrophils display a galectin-3 responsive phenotype accentuated by vaginal delivery. BMC Pediatr 2013; 13: 128.

263. Kollar S, Sandor N, Molvarec A, et al. Prevalence of intracellular galectin-1-expressing lymphocytes in umbilical cord blood in comparison with adult peripheral blood. Biol Blood Marrow Transplant 2012; 18: 1608-13.

264. Doverhag C, Keller M, Karlsson A, et al. Pharmacological and genetic inhibition of NADPH oxidase does not reduce brain damage in different models of perinatal brain injury in newborn mice. Neurobiol Dis 2008; 31: 133-44.

265. Bamberg C, Kalache KD. Prenatal diagnosis of fetal growth restriction. Semin Fetal Neonatal Med 2004; 9: 387-94.

266. Matthiesen L, Berg G, Ernerudh J, Ekerfelt C, Jonsson Y, Sharma S. Immunology of preeclampsia. Chem Immunol Allergy 2005; 89: 49-61.

267. ACOG Committee on Practice Bulletins--Obstetrics. ACOG practice bulletin. Diagnosis and management of preeclampsia and eclampsia. Number 33, January 2002. Obstet Gynecol 2002; 99: 159-67.

268. Sibai B, Dekker G, Kupferminc M. Pre-eclampsia. Lancet 2005; 365: 785-99.

269. Barker DJ. Fetal nutrition and cardiovascular disease in later life. Br Med Bull 1997; 53: 96-108.

270. Irgens HU, Reisaeter L, Irgens LM, Lie RT. Long term mortality of mothers and fathers after pre-eclampsia: population based cohort study. BMJ 2001; 323: 1213-7.

271. Powe CE, Levine RJ, Karumanchi SA. Preeclampsia, a disease of the maternal endothelium: the role of antiangiogenic factors and implications for later cardiovascular disease. Circulation 2011; 123: 2856-69.

272. Than NG, Vaisbuch E, Kim CJ, et al. Early-onset preeclampsia and 
HELLP syndrome: an overview. In: Preedy VR, ed. Handbook of growth and growth monitoring in health and disease. New York: Springer, 2012; 1867-91.

273. Ness RB, Roberts JM. Heterogeneous causes constituting the single syndrome of preeclampsia: a hypothesis and its implications. Am J Obstet Gynecol 1996; 175: 1365-70.

274. von Dadelszen P, Magee LA, Roberts JM. Subclassification of preeclampsia. Hypertens Pregnancy 2003; 22: 143-8.

275. Burton GJ, Jauniaux E. Placental oxidative stress: from miscarriage to preeclampsia. J Soc Gynecol Investig 2004; 11: 342-52.

276. Burton GJ, Woods AW, Jauniaux E, Kingdom JC. Rheological and physiological consequences of conversion of the maternal spiral arteries for uteroplacental blood flow during human pregnancy. Placenta 2009; 30: 473-82.

277. Roberts JM, Hubel CA. The two stage model of preeclampsia: variations on the theme. Placenta 2009; 30 Suppl A: S32-7.

278. Brosens IA, Robertson WB, Dixon HG. The role of the spiral arteries in the pathogenesis of preeclampsia. Obstet Gynecol Annu 1972; 1: $177-91$.

279. Brosens I, Pijnenborg R, Vercruysse L, Romero R. The "Great Obstetrical Syndromes" are associated with disorders of deep placentation. Am J Obstet Gynecol 2011; 204: 193-201.

280. Lee X, Keith JC Jr, Stumm N, et al. Downregulation of placental syncytin expression and abnormal protein localization in pre-eclampsia. Placenta 2001; 22: 808-12.

281. Chen CP, Chen CY, Yang YC, Su TH, Chen H. Decreased placental GCM1 (glial cells missing) gene expression in pre-eclampsia. Placenta 2004; 25: 413-21.

282. Roberts JM, Taylor RN, Musci TJ, Rodgers GM, Hubel CA, McLaughlin MK. Preeclampsia: an endothelial cell disorder. Am J Obstet Gynecol 1989; 161: 1200-4.

283. Sacks GP, Studena K, Sargent K, Redman CW. Normal pregnancy and preeclampsia both produce inflammatory changes in peripheral blood leukocytes akin to those of sepsis. Am J Obstet Gynecol 1998; 179: 80-6.

284. Maynard SE, Min JY, Merchan J, et al. Excess placental soluble fmslike tyrosine kinase 1 (sFlt1) may contribute to endothelial dysfunction, hypertension, and proteinuria in preeclampsia. J Clin Invest 2003; 111: 649-58.

285. Chaiworapongsa T, Romero R, Espinoza J, et al. Evidence supporting a role for blockade of the vascular endothelial growth factor system in the pathophysiology of preeclampsia. Young Investigator Award. Am J Obstet Gynecol 2004; 190: 1541-7.

286. Gupta AK, Hasler P, Holzgreve W, Gebhardt S, Hahn S. Induction of neutrophil extracellular DNA lattices by placental microparticles and IL-8 and their presence in preeclampsia. Hum Immunol 2005;
66: 1146-54.

287. Levine RJ, Lam C, Qian C, et al. Soluble endoglin and other circulating antiangiogenic factors in preeclampsia. N Engl J Med 2006; 355: 992-1005.

288. Venkatesha S, Toporsian M, Lam C, et al. Soluble endoglin contributes to the pathogenesis of preeclampsia. Nat Med 2006; 12: 642-9.

289. Rusterholz C, Holzgreve W, Hahn S. Oxidative stress alters the integrity of cell-free mRNA fragments associated with placenta-derived syncytiotrophoblast microparticles. Fetal Diagn Ther 2007; 22: 313-7.

290. Burton GJ, Yung HW, Cindrova-Davies T, Charnock-Jones DS. Placental endoplasmic reticulum stress and oxidative stress in the pathophysiology of unexplained intrauterine growth restriction and early onset preeclampsia. Placenta 2009; 30 Suppl A: S43-8.

291. Rusterholz C, Messerli M, Hoesli I, Hahn S. Placental microparticles, DNA, and RNA in preeclampsia. Hypertens Pregnancy 2011; 30: 364-75.

292. Redman CW, Sargent IL, Staff AC. IFPA Senior Award Lecture: making sense of pre-eclampsia - two placental causes of preeclampsia? Placenta 2014; 35 Suppl: S20-5.

293. Webster RP, Roberts VH, Myatt L. Protein nitration in placenta: functional significance. Placenta 2008; 29: 985-94.

294. Burton GJ, Yung HW. Endoplasmic reticulum stress in the pathogenesis of early-onset pre-eclampsia. Pregnancy Hypertens 2011; 1: 72-8.

295. Thijssen VL, Postel R, Brandwijk RJ, et al. Galectin-1 is essential in tumor angiogenesis and is a target for antiangiogenesis therapy. Proc Natl Acad Sci US A 2006; 103: 15975-80.

296. Sasaki Y, Darmochwal-Kolarz D, Suzuki D, et al. Proportion of peripheral blood and decidual CD4(+) CD25(bright) regulatory $\mathrm{T}$ cells in pre-eclampsia. Clin Exp Immunol 2007; 149: 139-45.

297. Toldi G, Saito S, Shima T, et al. The frequency of peripheral blood CD4+ CD25high FoxP3+ and CD4+ CD25- FoxP3+ regulatory T cells in normal pregnancy and pre-eclampsia. Am J Reprod Immunol 2012; 68: 175-80.

298. Saito S, Sakai M, Sasaki Y, Nakashima A, Shiozaki A. Inadequate tolerance induction may induce pre-eclampsia. J Reprod Immunol 2007; 76: 30-9.

299. Miko E, Meggyes M, Bogar B, et al. Involvement of Galectin-9/TIM3 pathway in the systemic inflammatory response in early-onset preeclampsia. PLoS One 2013; 8: e71811.

300. Gebhardt S, Bruiners N, Hillermann R. A novel exonic variant (221delT) in the LGALS13 gene encoding placental protein 13 (PP13) is associated with preterm labour in a low risk population. J Reprod Immunol 2009; 82: 166-73.

301. Shimizu H, Sekizawa A, Purwosunu Y, et al. PP13 mRNA expres- 
sion in the cellular component of maternal blood as a marker for preeclampsia. Prenat Diagn 2009; 29: 1231-6.

302. Farina A, Zucchini C, Sekizawa A, et al. Performance of messenger RNAs circulating in maternal blood in the prediction of preeclampsia at 10-14 weeks. Am J Obstet Gynecol 2010; 203: 575.e1-7.

303. Huppertz B, Meiri H, Gizurarson S, Osol G, Sammar M. Placental protein 13 (PP13): a new biological target shifting individualized risk assessment to personalized drug design combating pre-eclampsia. Hum Reprod Update 2013; 19: 391-405.

304. Khalil A, Cowans NJ, Spencer K, Goichman S, Meiri H, Harrington K. First trimester maternal serum placental protein 13 for the prediction of pre-eclampsia in women with a priori high risk. Prenat Diagn 2009; 29: 781-9.

305. Audibert F, Boucoiran I, An N, et al. Screening for preeclampsia using first-trimester serum markers and uterine artery Doppler in nulliparous women. Am J Obstet Gynecol 2010; 203: 383.e1-8.

306. Akolekar R, Syngelaki A, Sarquis R, Zvanca M, Nicolaides KH. Prediction of early, intermediate and late pre-eclampsia from maternal factors, biophysical and biochemical markers at 11-13 weeks. Prenat Diagn 2011; 31: 66-74.

307. Odibo AO, Zhong Y, Goetzinger KR, et al. First-trimester placental protein 13 , PAPP-A, uterine artery Doppler and maternal characteristics in the prediction of pre-eclampsia. Placenta 2011; 32: 598-602.

308. Di Lorenzo G, Ceccarello M, Cecotti V, et al. First trimester maternal serum PIGF, free beta-hCG, PAPP-A, PP-13, uterine artery Doppler and maternal history for the prediction of preeclampsia. Placenta 2012; 33: 495-501.

309. El Sherbiny WS, Soliman A, Nasr AS. Placental protein 13 as an early predictor in Egyptian patients with preeclampsia, correlation to risk, and association with outcome. J Investig Med 2012; 60: 818-22.

310. Moslemi Zadeh N, Naghshvar F, Peyvandi S, Gheshlaghi P, Ehetshami S. PP13 and PAPP-A in the First and Second Trimesters: Predictive Factors for Preeclampsia? ISRN Obstet Gynecol 2012; 2012: 263871.
311. Myatt L, Clifton RG, Roberts JM, et al. First-trimester prediction of preeclampsia in nulliparous women at low risk. Obstet Gynecol 2012; 119: 1234-42.

312. Schneuer FJ, Nassar N, Khambalia AZ, et al. First trimester screening of maternal placental protein 13 for predicting preeclampsia and small for gestational age: in-house study and systematic review. Placenta 2012; 33: 735-40.

313. Svirsky R, Meiri H, Herzog A, Kivity V, Cuckle H, Maymon R. First trimester maternal serum placental protein 13 levels in singleton vs. twin pregnancies with and without severe pre-eclampsia. J Perinat Med 2013; 41: 561-6.

314. Cuckle HS. Screening for pre-eclampsia: lessons from aneuploidy screening. Placenta 2011; 32 Suppl: S42-8.

315. Spencer K, Cowans NJ, Chefetz I, Tal J, Kuhnreich I, Meiri H. Second-trimester uterine artery Doppler pulsatility index and maternal serum PP13 as markers of pre-eclampsia. Prenat Diagn 2007; 27: 258-63.

316. Kuc S, Wortelboer EJ, van Rijn BB, Franx A, Visser GH, Schielen PC. Evaluation of 7 serum biomarkers and uterine artery Doppler ultrasound for first-trimester prediction of preeclampsia: a systematic review. Obstet Gynecol Surv 2011; 66: 225-39.

317. Nicolaides KH. Turning the pyramid of prenatal care. Fetal Diagn Ther 2011; 29: 183-96.

318. Than NG, Balogh A, Romero R, et al. Placental protein 13 (PP13): a placental immunoregulatory galectin protecting pregnancy. Front Immunol 2014; 5: 348.

319. Grimpel YI, Kivity V, Cohen A, et al. Effects of calcium, magnesium, low-dose aspirin and low-molecular-weight heparin on the release of PP13 from placental explants. Placenta 2011; 32 Suppl: S55-64.

320. Sammar M, Nisemblat S, Fleischfarb Z, et al. Placenta-bound and body fluid PP13 and its mRNA in normal pregnancy compared to preeclampsia, HELLP and preterm delivery. Placenta 2011; 32 Suppl: S30-6. 